\title{
Pharmacotherapy of Lower Respiratory Tract Infections in Elderly-Focused on Antibiotics
}

OPEN ACCESS

Edited by:

Min Yang,

Anhui Medical University,

China

Reviewed by:

Yaser Mohammed Al-Worafi,

Ajman University of

Science and Technology,

United Arab Emirates

Natasa Duborija-Kovacevic,

University of Montenegro,

Montenegro

${ }^{*}$ Correspondence:

Birong Dong

birongdong@163.com

Specialty section: This article was submitted to

Pharmaceutical Medicine and

Outcomes Research,

a section of the journal

Frontiers in Pharmacology

Received: 28 June 2019 Accepted: 27 September 2019 Published: 31 October 2019

Citation:

Liu Y, Zhang Y, Zhao W, Liu X, Hu F and Dong B (2019) Pharmacotherapy of Lower Respiratory Tract Infections in Elderly-Focused on Antibiotics.

Front. Pharmacol. 10:1237.

doi: 10.3389/fphar.2019.01237

\author{
Yang Liu1,2, Yan Zhang 1,2, Wanyu Zhao 1,2, Xiaolei Liu ${ }^{1,2}$, Fengjuan Hu ${ }^{1,2}$ and Birong Dong ${ }^{1,2 *}$ \\ ${ }^{1}$ The Center of Gerontology and Geriatrics, West China Hospital, Sichuan University, Chengdu, China, ${ }^{2}$ Geriatric Health Care \\ and Medical Research Center, Sichuan University, Chengdu, China
}

Lower respiratory tract infections (LRTIS) refer to the inflammation of the trachea, bronchi, bronchioles, and lung tissue. Old people have an increased risk of developing LRTIs compared to young adults. The prevalence of LRTls in the elderly population is not only related to underlying diseases and aging itself, but also to a variety of clinical issues, such as history of hospitalization, previous antibacterial therapy, mechanical ventilation, antibiotic resistance. These factors mentioned above have led to an increase in the prevalence and mortality of LRTIs in the elderly, and new medical strategies targeting LRTIS in this population are urgently needed. After a systematic review of the current randomized controlled trials and related studies, we recommend novel pharmacotherapies that demonstrate advantages for the management of LRTIs in people over the age of 65. We also briefly reviewed current medications for respiratory communicable diseases in the elderly. Various sources of information were used to ensure all relevant studies were included. We searched Pubmed, MEDLINE (OvidSP), EMBASE (OvidSP), and ClinicalTrials.gov. Strengths and limitations of these drugs were evaluated based on whether they have novelty of mechanism, favorable pharmacokinetic/pharmacodynamic profiles, avoidance of interactions and intolerance, simplicity of dosing, and their ability to cope with challenges which was mainly evaluated by the primary and secondary endpoints. The purpose of this review is to recommend the most promising antibiotics for treatment of LRTIs in the elderly (both in hospital and in the outpatient setting) based on the existing results of clinical studies with the novel antibiotics, and to briefly review current medications for respiratory communicable diseases in the elderly, aiming to a better management of LRTIs in clinical practice.

Keywords: lower respiratory tract infections, elderly, controlled clinical trial, pharmacotherapy, antibiotics, drug resistance

\section{INTRODUCTION}

The elderly may suffer from inappropriate medication due to decreased vision, memory loss, impaired cognition, low compliance, and unsupervised care. Hospitalization history, previous antibacterial therapy, physical decline, and mechanical ventilation are risk factors for LRTIs in this population. In the elderly, infections usually manifest as atypical symptoms such as lethargy, loss of appetite and mental disorders, thus inexperienced caregivers tend to ignore the above symptoms leading to the missed diagnosis and inappropriate use of antibiotics, increasing disability 
and mortality in the elderly. One of the major causes of the growing LRTIs burden is increasing antimicrobial resistance. Streptococcus pneumonia (S. pneumonia), Clamydia pneumonia, Staphylococcus aureus and other bacterial pathogens remain the common causes of LRTIs. The resistances of these pathogens to macrolides and fluoroquinolones continue to increase at an alarming rate worldwide (Giske et al., 2008; Woodhead et al., 2011). For example, $48 \%$ of US isolates of S. pneumoniae tested were macrolide-resistant in 2014 (an increase from the $40 \%$ reported in 2008), and high-level macrolide resistance across the US was 33\% (Jones et al., 2010). This is also the case in Europe (Ales et al., 2013). Aside from S. pneumoniae, atypical LRTIs-causing pathogens, such as Mycoplasma pneumoniae, have also produced increased antibiotic resistance (Asche et al., 2008). In the elderly, due to the long-term use of broadspectrum antibiotics, immunosuppressants and invasive operations increase antibiotic resistance, ultimately leading to excess hospitalizations, treatment failures, and financial burdens. In addition, some physicians are not familiar with the physiological characteristics of the elderly or precautions for common medication, resulting in inappropriate use of antibiotics, such as: 1) Combination therapy with quinolones and warfarin increases the risk of bleeding in elderly patients, leading to QT prolongation; 2) Interaction between macrolides and statins may lead to rhabdomyolysis and acute kidney injury; 3) combination therapies with macrolides, fluoroquinolones, and sulfonylureas may cause severe hypoglycemia in the elderly. 4) Fluoroquinolones, macrolides, sulfonamides, nitrofurans, and $\beta$-lactams may cause damage to the central nervous system (CNS); and 5) fungal infections may be associated with the long-term use of antibiotics. In addition, antibiotics may affect the accuracy of diagnostic tests. Due to the high prevalence of LRTIs in the elderly both in hospital and outpatient setting (Table 1), the epidemiological differences, atypical clinical manifestations, and age-related variations in pharmacokinetics and pharmacodynamics make LRTIs management for the elderly more challenging, and standardized treatment at early stage of LRTIs is critical to reducing deaths and disability at present.

According to the 2017 Global Burden of Disease (GBD) Study (James et al., 2018), the burden of LRTIs in people older than 70 years old is still increasing in many regions (Troeger et al., 2017). Altered respiratory structure caused by aging (Song and Chang, 2017), impaired organ function (Poulose and Raju, 2014), changes of drug-susceptibility (Alldred et al., 2010), and chronic low grade inflammation (Boyd and Orihuela, 2011) together lead to the increased susceptibility to LRTIs. Meanwhile, the existing

TABLE 1 | Major pathogens and risk factors for pneumonia in community and LTCFs.

\begin{tabular}{|c|c|c|c|}
\hline Pathogens & $\begin{array}{l}\text { Prevalence of } \\
\text { CAP in community } \\
\text { elderly }(\%)\end{array}$ & $\begin{array}{l}\text { Prevalence of } \\
\text { pneumonia in LTCFs } \\
\text { elderly }\end{array}$ & Risk factors \\
\hline $\begin{array}{l}\text { S. pneumoniae (Mufson and Stanek, 1999; Waterer } \\
\text { et al., 2001; Martinez et al., 2003; Baddour et al., 2004) }\end{array}$ & $5-58$ & $4-55$ & $\begin{array}{l}\text { Used lactams, fluoroquinolones, macrolides in the past } \\
3 \text { months; } \\
\text { COPD; } \\
\text { History of pneumonia in past } 12 \text { months; } \\
\text { Aspiration. }\end{array}$ \\
\hline $\begin{array}{l}\text { H. influenzae (Lau et al., 2006; Jean et al., 2009; Kuo } \\
\text { et al., 2014) }\end{array}$ & $2-29.4$ & $0-22$ & $\begin{array}{l}\text { Severe underlying disease; } \\
\text { Used antibiotics in the past } 3 \text { months; }\end{array}$ \\
\hline $\begin{array}{l}\text { Staphylococcus aureus (Wunderink et al., 2003; } \\
\text { Bernardo et al., 2004; Stevens et al., 2007; Kalil et al., } \\
\text { 2013; Bradley, 2014) }\end{array}$ & $0-7$ & $0-33$ & $\begin{array}{l}\text { Hospitalized in the past } 3 \text { months; Used antibiotics } \\
\text { in the past } 3 \text { months; Living in LTCFs; Received } \\
\text { intravenous therapy or dialysis for the past } 30 \text { days; } \\
\text { Confirmed MRSA by etiological diagnosis; Comorbidity; } \\
\text { Mental disorders. }\end{array}$ \\
\hline $\begin{array}{l}\text { Legionella (Miller, 1981; Edelstein et al., 1996; Genne } \\
\text { et al., 1997; Vergis et al., 2000; Blazquez Garrido } \\
\text { et al., 2005; Mykietiuk et al., 2005; Sabria et al., 2005; } \\
\text { Haranaga et al., 2007; Varner et al., 2011) }\end{array}$ & $0-17.5$ & $0-6$ & $\begin{array}{l}\text { Smoking; Chronic disease; Immunosuppression; } \\
\text { Air conditioning and hot water system use. }\end{array}$ \\
\hline $\begin{array}{l}\text { Gram-negative enteric bacilli (Ortiz-Ruiz et al., 2004; } \\
\text { Yakovlev et al., 2006; Peto et al., 2014) }\end{array}$ & $0-12.4$ & $0-14.3$ & $\begin{array}{l}\text { Living in LTCFs; Tube feeding; Comorbidity; } \\
\text { Cerebrovascular disease; Dementia; Use of Proton } \\
\text { pump inhibitors (PPIs). }\end{array}$ \\
\hline $\begin{array}{l}\text { Pseudomonas aeruginosa (Ding et al., 2016; Francois } \\
\text { et al., 2017; Bassetti et al., 2018; Ocheretyaner and } \\
\text { Park, 2018; Riquelme et al., 2018) }\end{array}$ & $1-17.1$ & $0-6$ & $\begin{array}{l}\text { Hospitalized in the past three months; Used antibiotics } \\
\text { in the past } 3 \text { months; } \\
\text { Aspiration; Impaired swallowing; } \\
\text { Use of PPIs; } \\
\text { Structural lung disease or severe bronchiectasis; } \\
\text { Confirmed pseudomonas aeruginosa in the past } 12 \\
\text { months; } \\
\text { Severe illness (requires ventilator or admission of ICU). }\end{array}$ \\
\hline $\begin{array}{l}\text { Chlamydia pneumonia (Arnold et al., 2016; Marchello } \\
\text { et al., 2016; Perrone and Quaglia, 2017; Webley and } \\
\text { Hahn, 2017) }\end{array}$ & $0-28$ & $0-18$ & \\
\hline Mycoplasma pneumoniae (Cao et al., 2017; de Groot & $1-13$ & 1 & \\
\hline
\end{tabular}


of comorbidities and aging, drug resistance, the prevalence and mortality of LRTIs in the elderly are much higher than other age groups, thus there is a huge demand for the development of novel pharmacotherapy for the elderly, and antibiotics seem to the cornerstone of LRTIs management (Katzan et al., 2003; Ma et al., 2013; Choi et al., 2018).

Based on the existing data of phase 3 clinical trials with the latest antibiotics, the purpose of this article is to recommend the most promising antibiotics for the treatment of LRTIs in the elderly. Meanwhile, we briefly reviewed current medications for respiratory communicable diseases in the elderly, aiming to obtain a better management of LRTIs in clinical practice.

\section{METHODOLOGY}

We comprehensively reviewed the research status of medication for LRTIs in the elderly and antibiotics, which are currently in advanced stages of development (phase 3 trial and beyond). After systematically retrieving the following sources including Pubmed, MEDLINE (OvidSP), and EMBASE (OvidSP) from October 2010 to July 2018, we have collected 87 clinical trials and manual screened out 58 trials (thirty-seven Phases 1 and 2 trials, eighteen Phase 3 trials, three Phase 4 trials, respectively), and finally elaborated the advantages and limitations of the application of novel antibiotics in clinical practice based on these trials.

All the random control trials (RCTs) included in our study share the following characteristics: trials included patients over 65 years of age who met at least three symptoms: cough, purulent sputum, dyspnea or pleurisy; if they had at least two abnormal vital signs, had at least one laboratory test result or clinical sign associated with LRTIs, and had radiologically confirmed pneumonia, these trials were classified as the risk classes in Pneumonia Severity Index (PSI), ranging from II to V. All of the trials we included were registered on ClinicalTrials.gov to assess the efficacy and safety of certain antibiotics. Population analysis, end points, and assessments were considered. Analysis populations including the intention-to-treat (ITT) population included all subjects who underwent randomization. The clinically evaluable (CE) population was defined as subjects who survive with resolution or improvement in symptoms and infections that further antibacterial therapy was not required. The microbiologic intention-to-treat (mITT) population was defined as all subjects in the ITT population who had a causative pathogen or pathogens identified at baseline by the culture of blood or respiratory specimens or using a culture-independent method. The clinical per-protocol population was defined as subjects in the ITT population who had a qualifying infection as defined by the trial entry criteria, had received a trial agent, had not received any antibacterial agent that was not as signed within the trial that could confound interpretation of the trial results, and had undergone an assessment of results during the protocol defined window. The microbiologic per-protocol population included the patients in both the clinical per-protocol population and the mITT population. Regarding end points, firstly the primary efficacy end point was evaluated as early clinical response
(ECR), which was defined as survival with improvement of one or more levels relative to baseline in two or more symptoms of pneumonia and no worsening of one or more levels in other symptoms of pneumonia, without receipt of rescue antibacterial therapy. Generally, ECR was assessed 24-72 h after the first dose of trial drug in the ITT population. The secondary end point was investigator-assessed clinical response at a post-treatment evaluation 5 to 10 days after the last dose, with clinical response defined as resolution or improvement in signs or symptoms to the extent that further antibacterial therapy was unnecessary. At the same time, we also evaluated the adverse reactions of antibiotics, including mild adverse events, serious adverse events (SAEs) defined as adverse events emerged after treatment initiation, and treatment discontinuation. The mortality in both arms was also analyzed for the safety of certain agents.

\section{ANTIBIOTICS FOR COMMUNITY ACQUIRED PNEUMONIA}

\section{Fluoroquinolone}

In recent years, new fluoroquinolone agents (Table 2), such as delafloxacin, nemonoxacin and zabofloxacin, have been identified as effective against existing fluoroquinolone-resistant pathogens. These new fluoroquinolone agents target both topoisomerase IV and DNA gyrase with stronger affinities, resulting in inhibition of bacterial DNA replication (Kollef and Betthauser, 2019), reducing mutant selection and toxic side effects, and resulting superior potent activity against the most common community acquired pneumonia (CAP) pathogens (Pfaller et al., 2017c). Delafloxacin is effective against Gram-positive bacteria, including methicillin sensitive Staphylococcus aureus (MSSA), methicillin resistant Staphylococcus aureus (MRSA), Moraxella catarrhalis (M. catarrhalis), and S. pneumoniae. While nemonoxacin is effective against Gram-positive bacteria, including multidrugresistant S. pneumoniae, MRSA, ertapenem-nonsusceptible Enterobacteriaceae, Legionella, Chlamydophila, and Mycoplasma. Antibacterial activity of zabofloxacin against MSSA and MRSA is similar to gemifloxacin, but 2-16 times stronger than that of moxifloxacin and ciprofloxacin (Park et al., 2006).

\section{Nemonoxacin}

RCT (NCT01529476) of a phase 3 was conducted in CAP patients receiving nemonoxacin $500 \mathrm{mg}$ or levofloxacin $500 \mathrm{mg}$ orally once daily for 7-10 days. A total of 527 patients (18-70 years old) were randomized to treat with nemonoxacin or levofloxacin. The clinical cure rates at test of cure (TOC) visit were $94.3 \%$ for nemonoxacin and $93.5 \%$ for levofloxacin in the mITT population. The microbiological success rates were $92.1 \%$ for nemonoxacin and $91.7 \%$ for levofloxacin in the mITT population. Nemonoxacin was as effective and safe as levofloxacin in the treatment of adult CAP patients in terms of clinical cure rates, microbiological success rates, and safety profile (Yuan et al., 2019). For other phrase 3, non-inferiority trials (NCT02205112, NCT03551210), in which old patients accounted for the majority of the participants, had repeatedly confirmed the safety and 
TABLE 2 | Summary of advantages and limitations of the novel antibiotics.

\begin{tabular}{|c|c|c|c|c|c|c|c|c|c|}
\hline Antibiotics & Mechanism of action & $\begin{array}{l}\text { Frequency of } \\
\text { interactions }\end{array}$ & Side effects & $\begin{array}{l}\text { Frequency } \\
\text { of dosing }\end{array}$ & $\begin{array}{l}\text { Phase of } \\
\text { study }\end{array}$ & $\begin{array}{l}\text { FDA/ } \\
\text { EMA } \\
\text { approved }\end{array}$ & $\begin{array}{l}\text { Intravenously } \\
\text { or orally }\end{array}$ & Recommend & $\begin{array}{l}\text { MIC }_{90} \text { of novel antibiotics compared with } \\
\text { existing antibiotics }\end{array}$ \\
\hline Nemonoxacin & $\begin{array}{l}\text {-Target both topoisomerase } \\
\text { IV and DNA gyrase. } \\
\text {-New fluoroquinolone. }\end{array}$ & LOW & $\begin{array}{l}\text { TRANSIENT } \\
\text { ELEVATION OF } \\
\text { AMINOTRANSFERASE. }\end{array}$ & $\begin{array}{l}\text { ONCE } \\
\text { DAlLY }\end{array}$ & 3 & YES & ORAL AND IV & A first-line medication. & 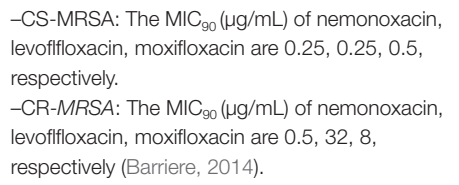 \\
\hline Zabofloxacin & $\begin{array}{l}\text {-Target both topoisomerase } \\
\text { IV and DNA gyrase. } \\
\text {-4th generation quinolone } \\
\text { (fluoroquinolone). }\end{array}$ & NOT PROVIDED & $\begin{array}{l}\text {-Mild, self-limiting. } \\
\text {-gastrointestinal (GI) } \\
\text { symptoms and allergic } \\
\text { reactions. }\end{array}$ & Once daily & 3 & NO & ORAL ONLY & Not recommend. & $\begin{array}{l}\text {-PSSP \& PISP \& PRSP: The MIC }{ }_{90}(\mathrm{mg} / \mathrm{mL} \text { ) of } \\
\text { zabofloxacin, ciprofloxacin } \\
\text { sparfloxacin are } 0.03,2,0.5 \text {, respectively } \\
\text { (Barriere, 2014). } \\
\text {-MRSA: The MIC } \mathrm{C}_{90}(\mu \mathrm{g} / \mathrm{mL} \text { ) of zabofloxacin, } \\
\text { moxifloxacin, levofloxacin are } 2,8 \text {, and } 16 \text {, } \\
\text { respectively (Mohamed et al., 2019). }\end{array}$ \\
\hline Delafloxacin & $\begin{array}{l}\text {-Target both topoisomerase } \\
\text { IV and DNA gyrase. } \\
\text {-4th generation quinolone } \\
\text { (fluoroquinolone). }\end{array}$ & Low & $\begin{array}{l}\text {-Favorable AEs profile. } \\
\text {-nausea, diarrhea. }\end{array}$ & Q12h & $\begin{array}{l}\text { III (STILL } \\
\text { PENDING) }\end{array}$ & NO & Oral and IV. & Not recommend & $\begin{array}{l}\text {-MRSA: The } \text { MIC }_{90}(\mathrm{mg} / \mathrm{L} \text { ) of delafloxacin, } \\
\text { moxifloxacin are } 0.004,0.032 \text { respectively. } \\
\text {-MSSA: The } \text { MIC }_{90} \text { (mg/L) of delafloxacin, } \\
\text { moxifloxacin are } 0.004,0.125 \text { respectively (Siala } \\
\text { et al., 2016). }\end{array}$ \\
\hline Omadacycline & $\begin{array}{l}\text {-A unique alkylaminomethyl } \\
\text { side chain at the c9 position } \\
\text { of the tetracycline }\end{array}$ & Low & $\begin{array}{l}\text {-Mild gastrointestinal } \\
\text { symptoms. } \\
\text {-CHANGES OF HR } \\
\text { AND QT INTERVAL. }\end{array}$ & Once daily & 3 & Yes & Oral and IV & $\begin{array}{l}\text {-Moderate. } \\
\text {-For the elderly } \\
\text { without cardiac } \\
\text { electrophysiological } \\
\text { abnormalities. }\end{array}$ & $\begin{array}{l}\text {-Chlamydia pneumoniae: The } \mathrm{MIC}_{90}(\mathrm{mg} / \mathrm{mL} \text { ) of } \\
\text { omadacycline, levofloxacin, moxifloxacin are } 0.25 \text {, } \\
0.5,1, \text { respectively (Roblin et al., } 1997) \text {. } \\
\text {-Mycoplasma pneumoniae } \\
: \text { The MIC } \mathrm{C}_{90}(\mu \mathrm{g} / \mathrm{mL} \text { ) of omadacycline, } \\
\text { doxycycline, tetracycline are } 0.25,0.5,0.5 \text {, } \\
\text { respectively (Waites et al., 2016). }\end{array}$ \\
\hline Solithromycin & $\begin{array}{l}\text {-The first fluoroketolide, } \\
\text { whichbinds to an additional } \\
\text { site on rRNA. }\end{array}$ & HIGH & $\begin{array}{l}\text { SEVER HEPATIC } \\
\text { TOXICITY }\end{array}$ & Once daily & 3 & NO & Oral and IV & Not recommend & $\begin{array}{l}\text {-MRSA: The } \text { MIC }_{90}(\mathrm{mg} / \mathrm{L} \text { ) of solithromycin, } \\
\text { telithromycin, azithromycin, clarithromycin are 2, } \\
4,2,8, \text { respectively. } \\
\text {-Legionella pneumoniae: The } \mathrm{MIC}_{90}(\mathrm{\mu g} / \mathrm{mL}) \\
\text { of solithromycin, azithromycin are } 0.03,1, \\
\text { respectively (Waites et al., 2016). }\end{array}$ \\
\hline Ceftaroline & $\begin{array}{l}\text { A strong affinity for PBPs - } \\
\text { Destroy cell wall formation. }\end{array}$ & Low & Mild and self-limiting & $\begin{array}{l}\text { THRICE } \\
\text { DAILY }\end{array}$ & 3 & Yes & IV ONLY & $\begin{array}{l}\text {-Moderate. } \\
\text {-For elderly Clearance } \\
\geq 30 \mathrm{ml} / \mathrm{min} \text {. } \\
\text {-For elderly without QT } \\
\text { prolongation. }\end{array}$ & $\begin{array}{l}\text {-Ceftriaxone-nonsusceptible (NS) s. pneumoniae: } \\
\text { The MIC } \mathrm{C}_{90}(\mu \mathrm{gg} / \mathrm{mL} \text { ) of ceftaroline, ceftriaxone are } \\
0.12, \geq 2 \text {, respectively. } \\
\text {-Amoxicillin-clavulanate-NS s. pneumoniae; } \\
\text { The MIC }{ }_{90} \text { ( } \mu \mathrm{g} / \mathrm{mL} \text { ) of ceftaroline, amoxicillin- } \\
\text { clavulanate are } 0.12, \geq 4 \text {, respectively. } \\
\text {-Levofloxacin-NS s. pneumoniae; The MIC }{ }_{90}(\mu \mathrm{\mu g} / \\
\mathrm{mL} \text { ) of ceftaroline, Amoxicillin-clavulanate are } \\
0.12, \geq 1 \text {, respectively (Pfaller et al., 2017b). }\end{array}$ \\
\hline Ceftobiprole & $\begin{array}{l}\text { A strong affinity for the } \\
\text { PBPs }\end{array}$ & Low & Mild and self-limiting & $\begin{array}{l}\text { THRICE } \\
\text { DAILY }\end{array}$ & 3 & NO & IV ONLY & $\begin{array}{l}\text {-Not recommend. } \\
\text {-Data in some centers } \\
\text { were unreliable. }\end{array}$ & $\begin{array}{l}\text {-Amoxicillin-resistant S. pneumoniae: The } \mathrm{MIC}_{90} \\
\text { ( } \mathrm{\mu g} / \mathrm{mL} \text { ) of ceftriaxone, ceftaroline, ceftobiprole } \\
\text { are } 0.25,0.06,0.06 \text {, respectively (Green et al., } \\
\text { 2014). }\end{array}$ \\
\hline
\end{tabular}


TABLE 2 | Continued

\begin{tabular}{|c|c|c|c|c|c|c|c|c|c|}
\hline Antibiotics & Mechanism of action & $\begin{array}{l}\text { Frequency of } \\
\text { interactions }\end{array}$ & Side effects & $\begin{array}{l}\text { Frequency } \\
\text { of dosing }\end{array}$ & $\begin{array}{l}\text { Phase of } \\
\text { study }\end{array}$ & $\begin{array}{l}\text { FDA/ } \\
\text { EMA } \\
\text { approved }\end{array}$ & $\begin{array}{l}\text { Intravenously } \\
\text { or orally }\end{array}$ & Recommend & $\begin{array}{l}\mathrm{MIC}_{90} \text { of novel antibiotics compared with } \\
\text { existing antibiotics }\end{array}$ \\
\hline Lefamulin & $\begin{array}{l}\text { Inhibit protein synthesis } \\
\text { by binding to the bacterial } \\
\text { ribosome. }\end{array}$ & $\begin{array}{l}\text {-HIGH, -Interact } \\
\text { with azole } \\
\text { antifungals and } \\
\text { midazolam. }\end{array}$ & Mild & $\begin{array}{l}\text { TWICE } \\
\text { DAILY }\end{array}$ & 3 & NO & Oral and IV & $\begin{array}{l}\text {-Moderate. } \\
\text {-For elderly without } \\
\text { taking azole antifungals, } \\
\text { midazolam. }\end{array}$ & $\begin{array}{l}\text {-Mycoplasma pneumoniae, macrolide- } \\
\text { susceptible: The MII } \mathrm{C}_{90}(\mu \mathrm{gg} / \mathrm{mL} \text { ) of lefamulin, } \\
\text { solithromycin, moxifloxacin, Tetracycline, } \\
\text { Doxycycline are } 0.02,0.5,0.25,1,0.25 \text {, } \\
\text { respectively. } \\
\text {-Mycoplasma. pneumoniae, macrolide-resistant: } \\
\text { The MIC } \mathrm{C}_{90}(\mathrm{\mu g} / \mathrm{mL} \text { ) of lefamulin, solithromycin, } \\
\text { moxifloxacin, tetracycline, doxycycline } \\
\text { are } 0.02, \mathrm{NA}, 0.25,1, \mathrm{NA} \text {, respectively } \\
\text { (Waites et al, 2017a). }\end{array}$ \\
\hline Pristinamycin & $\begin{array}{l}\text { Inhibits protein synthesis } \\
\text { by binding to the bacterial } \\
\text { ribosome 50s subunit }\end{array}$ & $\mathrm{HIGH}$ & Mild & $\begin{array}{l}\text { THRICE } \\
\text { DAILY }\end{array}$ & 3 & NO & ORAL ONLY & Not recommend & $\begin{array}{l}\text {-MRSA: The } \mathrm{MIC}_{90}(\mathrm{\mu g} / \mathrm{mL} \text { ) of pristinamycin, } \\
\text { linezolid, vancomycin, teicoplanin are } 0.5,0.5,2 \text {, } \\
\text { 2, respectively (Zmira et al., 2005). }\end{array}$ \\
\hline Iclaprim & $\begin{array}{l}\text { Selectively and potently } \\
\text { inhibits dihydrofolate } \\
\text { reductase. }\end{array}$ & Low & Mild & Twice daily & $\|$ & NO & IV ONLY & Not recommend (HAP) & $\begin{array}{l}\text { Vancomycin-NS MRSA: The MIC } \mathrm{C}_{90}(\mathrm{\mu g} / \mathrm{mL} \text { ) of } \\
\text { iclaprim, vancomycin are } 0.25,>4 \text {, respectively } \\
\text { (Huang et al., 2017). }\end{array}$ \\
\hline Telavancin & $\begin{array}{l}\text {-Interfering } \\
\text { transpeptidation, } \\
\text { polymerization. } \\
\text {-Increases potassium and } \\
\text { ATP leakage }\end{array}$ & $\begin{array}{l}\text {-HIGH. } \\
\text {-Interact with } \\
\text { digoxin, warfarin, } \\
\text { benzodiazepines. }\end{array}$ & Mild & Once daily & 4 & NO & IV ONLY & Moderate (HAP) & $\begin{array}{l}- \text { MRSA: The } \text { MIC }_{90}(\mu \mathrm{g} / \mathrm{mL} \text { ) of telavancin, } \\
\text { vancomycin, linezolid, levofloxacin are } 0.06,1,1 \text {, } \\
>4 \text {, respectively. } \\
-S \text {. pneumoniae: The } M \mathrm{MIC}_{90}(\mu \mathrm{g} / \mathrm{mL} \text { ) of telavancin, } \\
\text { vancomycin, linezolid, levofloxacin are } \leq 0.015 \text {, } \\
0.5,1,1 \text {, respectively (Duncan et al., 2017). }\end{array}$ \\
\hline Tedizolid & $\begin{array}{l}\text { Additional interactions with } \\
\text { conserved regions of the } \\
\text { ribosomal subunit and the } \\
\text { d-ring substituent. }\end{array}$ & Low & $\begin{array}{l}\text { REMAINS TO BE } \\
\text { SEEN. }\end{array}$ & Once daily & $\begin{array}{l}3 \\
\text { (UNFINISHED) }\end{array}$ & NO & IV and oral & Not recommend (HAP) & $\begin{array}{l}-M R S A: T h e M^{-} C_{90}(\mu \mathrm{g} / \mathrm{mL} \text { ) of tedizolid, linezolid, } \\
\text { vancomycin, Levofloxacin are } 0.12,1,1,>>4 \text {, } \\
\text { respectively (Duncan et all, 2017). }\end{array}$ \\
\hline Levofloxacin & $\begin{array}{l}\text { Target both topoisomerase } \\
\text { iv and dna gyrase }\end{array}$ & $\begin{array}{l}\text { Interact with } \\
\text { Warfarin, } \\
\text { theophylline, } \\
\text { NSAIDs }\end{array}$ & $\begin{array}{l}\text { Phototoxicity, systemic } \\
\text { active allergic reactions, } \\
\text { hepatotoxicity, severe } \\
\text { CNS toxicity }\end{array}$ & Twice daily & IV & YES & IV and oral & $\begin{array}{l}\text {-Moderate. } \\
\text {-Good post-marketing } \\
\text { response. }\end{array}$ & See above \\
\hline Ceftriaxone & $\begin{array}{l}\text { A higher affinity for PBPs. - } \\
\text { Destroy cell wall formation. }\end{array}$ & Low & $\begin{array}{l}\text { Eosinophilia, } \\
\text { leukopenia, } \\
\text { thrombocytopenia. }\end{array}$ & Once daily & IV & YES & IV only & $\begin{array}{l}\text {-Moderate. } \\
\text {-Good post-marketing } \\
\text { response. }\end{array}$ & See above \\
\hline Moxifloxacin & Topoisomerase ii, iv inhibitor & Low & $\begin{array}{l}\text { Diarrhea, fever, CNS, } \\
\text { toxicity }\end{array}$ & Once daily & IV & YES & IV and oral & $\begin{array}{l}\text {-Moderate. } \\
\text {-Good post-marketing } \\
\text { response. }\end{array}$ & See above \\
\hline Amoxicillin & $\begin{array}{l}\text { A higher affinity for pbp } \\
\text { and can destroy cell wall } \\
\text { formation more quickly and } \\
\text { effectively }\end{array}$ & Low & $\begin{array}{l}\text { Mild and self- } \\
\text { limiting,diarrhea, } \\
\text { headache, nausea, } \\
\text { anaphylaxis }\end{array}$ & Thrice daily & IV & YES & IV and oral & $\begin{array}{l}\text {-Moderate. } \\
\text {-Good post-marketing } \\
\text { response. }\end{array}$ & See above \\
\hline Linezolid & $\begin{array}{l}\text { Interactions with conserved } \\
\text { regions of the } 23 \text { s } \\
\text { ribosomal subunit and } \\
\text { the } \mathrm{d} \text {-ring substituent of } \\
\text { tedizolid. }\end{array}$ & Low & $\begin{array}{l}\text { Mild and self- } \\
\text { limiting,diarrhea, } \\
\text { headache, nausea }\end{array}$ & Thrice daily & IV & YES & IV and oral & $\begin{array}{l}\text {-Moderate(HAP) } \\
\text {-Good post-marketing } \\
\text { response. }\end{array}$ & See above \\
\hline Vancomycin & $\begin{array}{l}\text { Inhibit the synthesis } \\
\text { of bacterial RNA and } \\
\text { cell walls, and change } \\
\text { the permeability of cell } \\
\text { membranes. }\end{array}$ & Low & $\begin{array}{l}\text {-Acute kidney injury- } \\
\text { Vestibulocochlear nerve } \\
\text { damages }\end{array}$ & $\begin{array}{l}\text { Twice or } \\
\text { quartic } \\
\text { daily }\end{array}$ & IV & YES & IV only & $\begin{array}{l}\text {-Moderate(HAP) } \\
\text {-Good post-marketing } \\
\text { response. }\end{array}$ & See above \\
\hline
\end{tabular}

Reasons for recommending or not recommending have been marked in capital letters, such as IV, II, YES, NO, SEVER HEPATIC TOXIIITY; MIC $C_{90}$ the minimal inhibitory concentration required to inhibit the growth of 90\% of isolates; CR-MRSA, ciprofflloxacin-resistant and methicilin-resistant Staphylococcus aureus; PSSP, penicillin-susceptible Streptococcus pneumoniae; PISP, penicillin-intermediate S. pneumoniae; PRSP, penicillin-resistant S. pneumoniae; MRSA, methicilin resistant Staphylococcus aureus. 
efficacy of nemonoxacin in the treatment of CAP (van Rensburg et al., 2010; Chang et al., 2019).

\section{Values to the Elderly}

1) Novel mechanism of action: nemonoxacin targets both topoisomerase IV and DNA gyrase, inhibiting DNA synthesis required to bacterial growth (Li et al., 2015); 2) Frequency of interactions: when the creatinine clearance is $<50 \mathrm{~mL} / \mathrm{min}$, the dosage of levofloxacin need to be adjusted, while nemonoxacin does not induce or inhibit CYP1A2, 2B6, 2C8, 2C9, C19, and 3A4 isozymes (Cao et al., 2014). No dosage adjustment is required for the elderly with impaired renal or hepatic function. 3) Side effects: unlike other commercially available fluoroquinolone agents (moxifloxacin, levofloxacin), nemonoxacin does not exhibit evidences of phototoxicity, systemic active allergic reactions, significant hepatotoxicity, or severe CNS toxicity (Liang et al., 2013; Zhang et al., 2016). 4) Dosing regimen: In a systemic review and meta-analysis of RCTs demonstrated that compared with $500 \mathrm{mg}$ levofloxacin, nemonoxacin $(500 \mathrm{mg}$ or $750 \mathrm{mg}$ ) was more safe in cardiac conduction as measured by ECG QTc prolongation (Chang et al., 2019). In addition, a singledose escalation (nemonoxacin 25-1,250 mg) study shows that there were no clinically significant changes in corrected QT in healthy Chinese volunteers (Luke et al., 2010), but the $750 \mathrm{mg}$ dosage had a significantly higher risk of adverse effects than the $500 \mathrm{mg}$ dosage, so the nemonoxacin $500 \mathrm{mg}$ regimen may be adequate for the treatment of CAP (Roychoudhury et al., 2016). The oral dosage of nemonoxacin is $500 \mathrm{mg}$ once daily while it is $100 \mathrm{mg}$ twice daily for levofloxacin, making nemonoxacin a potential therapy for the elderly with LRTIs.

\section{Zabofloxacin}

Multicenter, non-inferior RCT (NCT01658020) of a phase 3 evaluated the safety and efficacy of oral zabofloxacin $(367 \mathrm{mg}$ once daily for 5 days) vs oral moxifloxacin ( $400 \mathrm{mg}$ once daily for 7 days) in treating acute bacterial exacerbation of chronic obstructive pulmonary disease (COPD); 345 participants with moderate acute bacterial exacerbation COPD were selected. In a subgroup of patients without chronic bronchitis but suffering from LRTIs, antibacterial efficacy of zabofloxacin and moxifloxacin therapies were observed, and the cure rates were $85.9 \%$ and $84.2 \%$, respectively. No statistical differences of acute AEs and serious AEs were detected between the two arms (Rhee et al., 2015).

\section{Values to the Elderly}

1) Novel mechanism of action: zabofloxacin can inhibit DNA gyrase and topoisomerase IV, thus inhibiting the bacterial DNA replication (Park et al., 2010). Zabofloxacin shows potent in vitro activity against $S$. pneumoniae isolates that caused invasive pneumococcal disease, even levofloxacin-resistant strains (Kwon et al., 2006). 2) Side effects: adverse effects include nausea, hypotension, somnolence, and an increase of blood phosphokinase, which are common and minor and will subside spontaneously. Meanwhile, no QT prolongation was detected
(Kocsis et al., 2016). 3) Dosing regimen: dosing regimen is relatively simple, requiring only one dose per day.

\section{Delafloxacin}

RCT (NCT02679573) of a phase 3 on comparison of delafloxacin and moxifloxacin for the treatment of adults with CAP was completed. At present, the results of this trial are still pending. Based on this situation, we do not recommend delafloxacin as a first-line agent for LRTIs in the elderly.

\section{Tetracycline Omadacycline}

Omadacycline (Table 2) was a novel once-daily aminomethylcycline antibiotic, and became the second tetracycline antibiotic approved by the FDA in 2018. Omadacycline has antimicrobial activity against Gram-positive, Gram-negative, anaerobic, and atypical pathogens (Dougherty et al., 2019). Omadacycline has a higher coverage against MRSA, penicillin- and multidrug-resistant S. pneumoniae, and Vancomycin-resistant enterococci (VRE). Omadacycline also has good activity against $H$. influenza, $M$. catarrhalis, $M$. pneumoniae, L. pneumophila, Enterobacteriaceae, Ureaplasma spp., Bacillus anthracis, Yersinia pestis, and Clostridium difficile (Pfaller et al., 2017a).

A phase 3 trial (NCT02531438) on the efficacy and safety of omacycline for CAP patients had been successfully completed. A total of 772 CAP patients (PSI: II-IV) were randomly enrolled into two groups of the equal size. Patients in the two groups took intravenous omadacycline or moxifloxacin in the first three days, and then transitioned to oral omadacycline or moxifloxacin, respectively. Overall, $41.9 \%$ of patients in the ITT populations were older than 65 years old, and $85.4 \%$ had PSI risk class of III or IV in this population. Study showed no significant differences between the two arms in terms of ECR, 5-10 days of clinical responses, and incidences of AEs. All the patients who died were older than 65 years old (eight in the omadacycline group and four in the moxifloxacin group). These deaths might be caused by progression of the underlying pneumonia or respiratory compromise, HAP, cardiac or vascular events, and cancer. Neither group had clinically relevant changes from baseline in vital signs, laboratory tests, nor ECG findings. Researchers concluded that deaths in both groups were related to underlying disease rather than these two antibiotics. In summary, the efficacy of omadacycline in the treatment of CAP was not inferior to that of moxifloxacin (Stets et al., 2019).

\section{Values to the Elderly}

1) Novel mechanism of action: the chemical structure of omadacycline contains a unique alkylaminomethyl side chain at the C9 position of the tetracycline. 2) Frequency of interactions: omadacycline has mild drug interactions and favorable safety profiles. In vitro, researchers found that omadacycline does not affect cytochrome P450, and that the most common AEs of omadacycline are gastrointestinal symptoms (2019). No clinically significant differences in omadacycline pharmacokinetics were 
observed based on age. There is no need for the elderly with impaired or and hepatic function to adjust dose of omadacycline. 3) Dosing regimen: dosing regimen is relatively simplistic as only one dose is needed per day. This regimen greatly reduces the likelihood that an impaired-cognitive patient take repeated medicine or forget to take the medicine.

\section{Macrolide Solithromycin}

Solithromycin (Table 2) is a novel 4th generation macrolide. It's the first fluoroketolide to complete phase 3 clinical trials and show activity against the pathogens associated with LRTIs, including macrolide/penicillin-resistant isolates of $S$. pneumoniae. Solithromycin influence the formation and function of $50 \mathrm{~S}$ ribosomal subunit, causing the frame-shift mutation during translation (Still et al., 2011). Due to the lack of a cladinose moiety, it does not induce erm(B)-mediated resistance (3Rd et al., 2015). And it is less susceptible to mef(A)-mediated efflux than other macrolides as a result of its increased ribosomal binding and greater intrinsic activity (Darpo et al., 2017a).

One trial (NCT01756339) compared the antibacterial efficacy and safety of oral solithromycin for the treatment of CAP in a 114 central non-inferiority RCTs. During this study, patients were randomly assigned (1:1) to receive either oral solithromycin or moxifloxacin. The results showed that $78.2 \%$ participants had an ECR in the solithromycin group compared with $77.9 \%$ in the moxifloxacin group, showing equivalent efficacy of solithromycin for the primary endpoint. Subjects over 65 years of age with a history of asthma and COPD had higher success rates for ECR and short term follow-up than those without COPD. In addition, the ECR rate is higher in the 75-year-old group, which may be related to the immunomodulatory effects of solithromycin among all groups (Barrera et al., 2016). In another phase 3 trial (NCT01968733), the efficacy and safety of intravenous-tooral solithromycin were assessed against intravenous-to-oral moxifloxacin for the treatment of CAP. In this trial, the ECR in the ITT population aged 65-74 years old and older than 75 year old showed non-inferiority of solithromycin for the primary endpoint, respectively. The incidence rate of serious AEs was comparable between groups with no significance (File et al., 2016).

\section{Values to the Elderly}

Solithromycin has many advantages to be provided for the elderly population. 1) Novel mechanism of action: solithromycin demonstrates increased ribosomal binding in comparison with other macrolides. Meanwhile, as the first fluoroketolide, fluorine contributes to tighter binding and increased activity, and the potential for resistance appears to be low (Darpo et al., 2017b). 2) Frequency of interactions: Due to it is inhibition of the CYP3A isoenzyme pathway it has frequent drug-drug interactions like other macrolides such as erythromycin and clarithromycin. 3) Side effects are mild and relatively low in frequency, however there are concerns of severe hepatic toxicity that require further evaluation (Hook et al., 2015). 4) Dosing regimen: solithromycin also has a simple dosing regimen, with once-daily dosing for the treatment of CAP. For the elderly with poor vision, memory loss, cognitive impairment, and low self-adherence, it's the preferred choice. Moreover, solithromycin is available in both oral and intravenous (IV) formulation, and is highly potent with effective bacteriostatic properties and eradication rates from a pharmacodynamics (PD) perspective.

\section{Cephalosporin}

Cephalosporins, including ceftobiprole and ceftaroline, is the "new-generation" which is effective against MRSA, MSSA, penicillin-resistant S. pneumoniae, Escherichia coli, and Pseudomonas aeruginosa (Green et al., 2014).

\section{Ceftaroline}

In 2010, ceftaroline (Table 2) was approved by the FDA and European Medicines Agency (EMA) for the treatment of CAP. Its broad-spectrum activity, especially its potent antibacterial activity against Gram-positive bacteria, makes ceftaroline an ideal antibiotic for the treatment of CAP. The efficacy and safety of ceftaroline are established in two milestone studies FOCUS 1 and FOCUS 2. FOCUS 1(NCT00621504) enrolled 613 CAP patients $49.2 \%$ of whom were aged $\geq 65$ years old. The experimental group was treated with intravenous ceftaroline $600 \mathrm{mg}$ Q12 h $\times$ 5-7 days, and the control group was treated with ceftriaxone and clarithromycin. FOCUS 2 (NCT00509106) recruited 627 CAP patients with the same criteria. Almost half (46.8\%) of the patients across both groups were aged $\geq 65$ years old. Both arms took the same intervention as FOCUS 1, and only clarithromycin was not used as adjuvant therapy in FOCUS 2. In both FOCUS 1 and 2, ceftaroline and ceftriaxone were well tolerated, with similar rates of AEs, serious AEs, deaths and discontinuations (File et al., 2011; Low et al., 2011). Another published RCT (NCT01371838) included 771 Asian CAP (PORT risk class III-IV) patients meeting the same criteria as FOCUS. The experimental group used exactly the same intervention as in FOCUS, and the control group used double dosage of ceftriaxone. The results show that ceftaroline is superior to ceftriaxone in clinically evaluable (CE) and mITT population. There was no significant difference in safety between the two agents (Zhong et al., 2015). A Phase 4 multicenter study (NCT01666743) was proposed to specifically evaluate the safety and efficacy of ceftaroline in the treatment of CAP in patients 65 years of age, but the study was withdrawn for unknown reasons. Other studies on the safety and efficacy of ceftaroline for CAP are being recruited (NCT02735707) or have not yielded results (NCT03025841).

\section{Values to Elderly}

(1) Novel mechanism of action: compared with other penicillin or cephalosporin $\beta$-lactam antibiotics, ceftaroline has a higher affinity for penicillin-binding proteins (PBPs) and can destroy cell wall formation more quickly and effectively (Justo et al., 2015). Its broad-spectrum activity, especially its potent antibacterial activity against resistant Gram-positive bacteria, makes it an ideal drug for the treatment of CAP. (2) Frequency of interactions and side effects: side effects of solithromycin are mild, and the frequency was relatively low. For elderly patients 
with moderate impaired renal function, ceftaroline does not require dose adjustment. (3) Dosing regimen: regimen is simple, and intravenous infusion twice a day is sufficient.

\section{Ceftobiprole}

Ceftobiprole (Table 2) has good activity against Gram-positive pathogens. It has species-dependent activity against Gramnegative pathogens (Curcio, 2014).

Two large scale in vitro studies (Farrell et al., 2014; Hodille et al., 2017) of ceftobiprole showed that ceftobiprole had strong activity against MSSA (100\%, 100\% susceptible, respectively), MRSA (98.3\%, 99.3\% susceptible, respectively), S. pneumoniae (99.3\%, 99.7\% susceptible, respectively), and the majority of Enterobacteriaceae (87.3\%, 82.5\% susceptible, respectively). The potency of ceftobiprole against P. aeruginosa $(64.6 \%, 72.7 \%$ susceptible, respectively) was similar to that of ceftazidime (Kresken et al., 2011). For elderly people in long-term care facilities (LTCFs), agents are necessary for the coverage of rare pathogens, while ceftobiprole has good antibacterial activity against common pathogens of LTCFs, such as Enterobacteriaceae and $P$. aeruginosa. Nowadays, ceftobiprole is approved in several European countries for the treatment of CAP and HAP (excluding VAP) (Scheeren, 2015).

The safety and efficacy of ceftobiprole have been demonstrated in two phase 3 trials on patients with CAP and HAP (excluding VAP). The first study (NCT00326287) demonstrated that intravenous ceftobiprole had equivalent efficacy to ceftriaxone with or without linezolid. Details: clinical cure rates for CAP patients were $86.6 \%$ vs $87.4 \%$ (clinical evaluate population, $95 \% \mathrm{CI},-6.9,5.3$ ), and $76.4 \%$ vs $79.3 \%$ (ITT population, $95 \%$ CI, -9.3, 3.6). Pneumonia-specific mortality within the first 30 days was very low in both groups. In addition, common and serious AEs in the ceftobiprole arm were mild and comparable to those in the ceftriaxone arm (Nicholson et al., 2012). The second RCT (NCT00210964) demonstrated ceftobiprole was non-inferior to ceftazidime with or without linezolid. It is worth noting that cure rates for VAP patients were $23.1 \%$ vs $36.8 \%$ and $37.7 \%$ vs $55.9 \%$, suggesting that ceftobiprole was unsuitable for the treatment of VAP (Awad et al., 2014). A retrospective study of the above RCTs evaluated the early clinical improvement in subgroups of high-risk patients. In some subgroups of high-risk patients with CAP (such as patients over 75 years old, or or CAP patients with COPD, or HAP patients with more than 10 baseline comorbidities), particular and significant results were observed that seemed to favor the ceftobiprole over comparators (Pooley et al., 2014).

\section{Values to Elderly}

(1) Novel mechanism of action: ceftobiprole with a strong affinity for the PBPs, is responsible for the antibacterial activity of staphylococci and pneumococci (Falco et al., 2018). For pneumonia patients with comorbidities, ceftobiprole with the strong bactericidal effect can quickly improve clinical symptoms and ensure a better prognosis. (2) Frequency of interactions: ceftobiprole elimination is not expected to be significantly affected, as this is a minor elimination route, but dose adjustment is necessary for subjects with the renal impairment (Pfaller et al.,
2019). (3) Side effects: for comorbid patients older than 75 years old, the incidence of adverse events caused by ceftobiprole is similar to that of non-high-risk patients, suggesting that ceftobiprole is safe and effective for high-risk groups. In addition, ceftobiprole is less likely to cause an antibiotic-related intestinal flora disorder (Horn et al., 2017).

\section{Pleuromutilin}

\section{Lefamulin}

Lefamulin (Table 2) is a potent semi-synthetic antibacterial agent belonging to a novel class known as the pleuromutilins. Lefamulin's in vitro antibacterial profile includes the most important bacterial pathogens causing LRTIs. The antibacterial spectrum comprises S. pneumoniae, $H$. influenzae, $M$. catarrhalis, the atypical respiratory pathogens, $M R S A$, $\beta$-haemolytic streptococci, and Enterococcus faecium (Waites et al., 2017a; Veve and Wagner, 2018). Moreover, as demonstrated in cross-resistance studies, lefamulin remains active against clinical isolates resistant to the following antibiotics: macrolides, lincosamides, streptogramin B, oxazolidinones, tetracyclines, $\beta$-lactams, quinolones, trimethoprim-sulfametoxazole, mupirocin, and vancomycin (Mendes et al., 2019; Paukner et al., 2019).

The phase 3 clinical trial, LEAP1 (NCT02559310), for evaluating the safety and efficacy of lefamulin for the treatment of CAP has been completed. Participants with CAP were randomized $1: 1$ to receive lefamulin at $150 \mathrm{mg}$ IV every $12 \mathrm{~h}$ or moxifloxacin at $400 \mathrm{mg}$ once daily. After six doses, patients could be switched to an oral administration if pre-specified improvement criteria were met. If MRSA was suspected, linezolid was added to moxifloxacin. In LEAP1, patients aged over 65 years old accounted for $47.8 \%$ and $39.3 \%$ of the lefamulin and moxifloxacin groups, respectively. At this age, lefamulin was non-inferior to moxifloxacin for ECR, or investigators assessed clinical response (IACR). Lefamulin has a low incidence of drug resistance and minimal cross-resistance with other types of antibiotics, making it a new monotherapy for elderly CAP (File et al., 2019). The oral dosage form of lefamulin is under the investigation in LEAP 2 (NCT02813694), and the primary endpoint is similar to LEAP 1. A major difference in study design includes the use of only oral drugs without the addition of linezolid in the moxifloxacin group. The LEAP 2 results are expected to be available in the second half of 2019.

\section{Values to Elderly}

In LEAP 1, patients $\geq 65$ years of age accounted for $47.8 \%$ and $39.3 \%$ of the lefamulin and moxifloxacin groups, respectively. At this age, lefamulin was non-inferior to moxifloxacin for ECR or IACR. (1) Novel mechanism of action: inhibit protein synthesis by binding to the bacterial ribosome $50 \mathrm{~S}$ subunit (Veve and Wagner, 2018), which ensures that lefamulin has a low incidence of drug resistance and minimal cross-resistance with other types of antibiotics, making it a new monotherapy for elderly CAP. (2) Frequency of interactions: lefamulin has little inhibitory effect on CYP3A, however, it's worth noting that its high protein binding capacity could lead to drugs interaction (Waites et al., 2017a). (3) Side effects: lefamulin only 
has mild side effects and is highly effective against common CAP pathogens (Mendes et al., 2019).

\section{Streptogramins \\ Pristinamycin}

Pristinamycin (Table 2) is a streptococcal-type antibiotic produced by Streptomyces faecalis. It inhibits protein synthesis by binding to the bacterial ribosome 50S subunit (Nespoulous et al., 2018). Pristinamycin has strong antibacterial activity against MRSA, MSSA, H. influenzae, and S. pneumonia (Cooper et al., 2014). In addition, pristinamycin has a synergistic antibacterial effect with vancomycin (Reid et al., 2010).

A phase 4 study (NCT02332577) intended to evaluate the safety and efficacy of pristinamycin in the treatment of mild CAP is expected to be completed in May 2021.

\section{Values to Elderly}

It is noteworthy that the above trials excluded patients with moderate and severe CAP, which may limit its generalizability. In addition, pristinamycin has only oral formulation, so it's unlikely that it will ever have a role in treating old patients with severe CAP. We do not recommend pristinamycin as a promising treatment for CAP.

\section{ANTIBIOTICS FOR HOSPITAL ACQUIRED PNEUMONIA OR LTCFS ACQUIRED PNEUMONIA}

\section{Dihydrofolate-Reductase Inhibitor Iclaprim}

Iclaprim (Table 2) is a broad-spectrum diaminopyrimidine antibiotic that inhibits the dihydrofolate reductase and does not cross react with human enzyme (Laue et al., 2007). Iclaprim is being developed to treat serious respiratory infections, such as hospital acquired pneumonia (HAP), attributed to multidrugresistant Gram-positive pathogens and cystic fibrosis caused by $S$. aureus (Huang et al., 2018; Huang et al., 2019). Until now, only one phase 2 clinical trial (NCT00543608) has focused on exploring iclaprim's efficacy on HAP caused by Gram-positive bacteria, but the trial has not been completed. Therefore, iclaprim is not recommended as a routine treatment for elderly HAP.

\section{Lipoglycopeptides \\ Telavancin}

Telavancin (Table 2) is a novel semi-synthetic lipoglycopeptides that is active against multidrug resistant (MDR) staphylococci, enterococci, and streptococci. Telavancin was approved by the FDA in 2013 for the HAP and ventilator-associated bacterial pneumonia (VABP). Telavancin has high antibacterial efficacy against $S$. aureus $\left(\mathrm{MIC}_{90}=0.5 \mathrm{mg} / \mathrm{L}\right), S$. epidermidis $\left(\mathrm{MIC}_{90}=0.5 \mathrm{mg} / \mathrm{L}\right)$ (both MSSA and MRSA), VISA $\left(\mathrm{MIC}_{90}=\right.$ $0.5 \mathrm{mg} / \mathrm{L})$, Streptococcus $\left(\mathrm{MIC}_{90}=0.03 \mathrm{mg} / \mathrm{L}\right)$, and $\mathrm{VanB}$ protein enterococcus $\left(\mathrm{MIC}_{90}=2 \mathrm{mg} / \mathrm{L}\right)$, but has a poor effect on $V R S A$ $\left(\mathrm{MIC}_{90}=8 \mathrm{mg} / \mathrm{L}\right)$ and VanA protein, enterococcus $\left(\mathrm{MIC}_{90}=\right.$
$8 \mathrm{mg} / \mathrm{L})$ (Hassoun et al., 2017). Two RCTs named "ATTAIN" enrolled in more than $700 \mathrm{HAP}$ patients who were randomized to receive telavancin $(10 \mathrm{mg} / \mathrm{kg}, \mathrm{QD})$ or vancomycin (1 g, $\mathrm{Q} 12 \mathrm{H})$. The results of the study indicate that telavancin was no worse than vancomycin in terms of the clinical cure rate of TOC visits in both ATTAIN studies. The subgroup analysis also showed that telavancin had a better effect on simple $S$. aureus infection, while vancomycin had a better effect on mixed infection of Gram-positive and Gram-negative bacteria. For MRSA, telavancin and vancomycin have similar effects and similar rates of AEs, but telavancin causes a higher proportion of people with elevated serum creatinine levels than vancomycin (10\% vs $8 \%$ ) (Barriere, 2014). In summary, ECG monitoring is necessary for elderly patients with a history of QT prolongation. At the same time, patients using telavancin should be monitored for coagulation parameters before and after dosing (Al Jalali and Zeitlinger, 2018).

\section{Values to Elderly}

1) Novel mechanism of action: telavancin has a dual antibacterial mechanism of action, which is to inhibit bacterial cell wall synthesis by interfering with cross-linking (transpeptidation) and polymerization (Rubinstein et al., 2011). Meanwhile, telavancin can cause cell death by increasing membrane permeability, resulting in the leakage of intracellular potassium and ATP. 2) Frequency of interactions: telavancin has mild inhibitory effect on CYP3A (Das et al., 2017), thus it can also be used in elderly with hepatic dysfunction. However, it's worth noting that its high protein binding capacity could lead to drug to drug interaction (Al Jalali and Zeitlinger, 2018). 3) Side effects: telavancin only has mild side effects and high potency for common CAP pathogens. 4) Dosing regimen: the single-dosage or two-dosage regimen can greatly improve the compliance of old patients. In addition, compared with vancomycin, telavancin has the advantages of potent antibacterial activity against MRSA, VISA and even VRSA as well as long half-life. It has good antibacterial activity. It can fill in gaps when vancomycin is resistant (Barriere, 2014). Based on all the above details, we moderately recommend telavancin as a promising antibiotic for LRTIs in elderly.

\section{Oxazolidinone Tedizolid}

Tedizolid (Table 2) was approved by the FDA for the treatment of acute bacterial skin and skin structure infections (ABSSSIs) in 2016. Tedizolid is one of very few prospective agents with a spectrum of activity against MRSA and VRE, which are common pathogens in nosocomial pneumonia (Flanagan et al., 2013). Tedizolid shares many structural features with linezolid and has increased antimicrobial potency than linezolid. Many studies have confirmed that the antibacterial potential of tedizolid for linezolid-susceptible and linezolid-resistant Gram-positive pathogens is much higher than that of linezolid (Brown and Traczewski, 2010). To date, no phase 3 trials assessing efficacy of tedizolid for the treatment of HAP have been completed. Until now, no documented short-term animal and clinical studies have 
reported neuropathies or thrombocytopenia associated with tedizolid, but the safety of tedizolid for long-term administration remains to be seen.

A randomized phase 3 study (NCT02019420) of the safety and efficacy of tedizolid in comparison with linezolid in patients with HAP and VAP is currently ongoing. The primary endpoint is to determine the non-inferiority (NI) in all-cause mortality (ACM) within 28 days after the randomization of intravenous tedizolid phosphate compared with intravenous linezolid in the ITT Analysis Set in ventilated participants with Gram-positive nosocomial pneumonia. The result is expected to be completed by February 2018, but the researchers have not announced the results of the trial.

\section{Values to Elderly}

1) Novel mechanism of action: additional interaction with conserved regions of the ribosomal subunit and the D-ring substituent of tedizolid contributes to its strong antibacterial potential. The level of tedizolid penetration into epithelial lining fluid (ELF) and alveolar macrophages (AM) is much higher than free-drug exposures in plasma (Housman et al., 2012). 2) Side effects: in the presence of linezolid resistance or hematologic side effects (Lodise et al., 2016), tedizolid is a better choice. 3) Frequency of interactions: for the elderly with any degree of hepatic and renal dysfunction, no dose adjustment was warranted in elderly to achieve therapeutic goals. 4) Dosing regimen: in addition, its better bioavailability, food-independent efficacy, and simple dosing regimens that support once daily administration, making tedizolid popular with clinicians.

\section{SPECIAL CONSIDERATION}

We briefly review the current status of pharmacotherapies for special types of LRTIs in elderly. We searched the following sources including Pubmed, MEDLINE (OvidSP), EMBASE (OvidSP), from July 2015 to July 2018. We finally concluded that the risk of LRTIs is much higher in immunocompromised old adults with diabetes than healthy elderly. Pharmacotherapies for old patients with special types of LRTIs (fungal pneumonia, respiratory $\mathrm{HCoVs}$, influenza) are basically the same as for all age groups, but at the same time, considering the health status (frailty, long-term lying in bed, recurring infection and excess hospitalization, cognitive impairment), comorbidities, medication and vaccination history are also important for developing individualized medication regimens.

\section{Diabetes Mellitus}

A retrospective study of patients with diabetes reveals a high correlation between prevalence of infection and fasting blood glucose (FBG) in the elderly (Rayfield et al., 1982). In addition, among patients admitted to hospital for LRTIs, the admission rate of patients with diabetes (Winterbauer et al., 1969; Kornum et al., 2007; Peleg et al., 2007; Casqueiro et al., 2012), risk of complications (Peleg et al., 2007) and mortality (Fine et al., 1996;
Kornum et al., 2007) were significantly higher than patients without diabetes. Double hit from an aging immune system, host defense may be impaired in diabetes together increase the risk of bacterial, mycobacterial, fungal and viral infections. Furthermore, respiratory dysfunction and microangiopathy together lead to a higher morbidity and mortality in diabetes elderly (Kornum et al., 2007).

Antimicrobial pharmacotherapy for elderly with diabetes is the same as for all age groups (Mandell et al., 2003). Data suggest that elderly patients receiving aminoglycosides have worse outcomes (Gleason et al., 1999), and medication regimen should be individualized, taking into account the patient's recent antibiotic medication history, comorbidities, suspected aspiration, suspected pseudomonas infection and $\beta$-lactam allergy. For pneumonia patients with diabetes, patients who have not recently used antibiotics can take advanced macrolides or a respiratory fluoroquinolone. By contrast, Patients who have used antibiotics recently can choose fluoroquinolone and advanced macrolides. The chronic use of inhaled glucocorticoids in elderly is associated with the increased risk of diabetes, physicians should be aware of this in order to select those patients in whom the benefits will outweigh the risks (Battaglia et al., 2015). At the same time, it is also important for the management of blood glucose level in infected patients. Meanwhile, diabetic patients usually have varying degrees of impaired renal function, antibiotics with nephrotoxicity should be avoided.

\section{Fungal Pneumonia}

Pulmonary fungal infections can occur in old patients with normal or impaired immune function. The morbidity and mortality of fungal pneumonia among the elderly have increased significantly in recent years. The reason is the increase in patients with malignant tumors, as well as organ transplants or autoimmune diseases, resulting in an increase in patients with immunocompromise, leading to an increase in the incidence of fungal pneumonia (Limper et al., 2011; Chen et al., 2018).

Candida pneumonia is rare; in fact, the isolation of Candida from respiratory secretions is of no clinical significance in most cases (Chen et al., 2018). For immunecompetent pulmonary cryptococcosis hosts, fluconazole or itraconazole are recommended, while immunocompromised hosts are recommended to be treated with amphotericin $B$ in combination with flucytosine, and then followed by fluconazole or itraconazole ( $\mathrm{Li}$ et al., 2017). In patients with normal immune function, patients with pulmonary aspergillosis are recommended to inhale glucocorticoids and bronchodilators and leukotriene receptor antagonists (Denning et al., 2016), while immunocompromised patients with invasive pulmonary aspergillosis are advised to take oral fluconazole or itraconazole or intravenous amphotericin B (Blanchard et al., 2018). For elderly patients with immunodeficiency, intravenous caspofungin or micafungin is recommended, then followed by oral fluconazole or itraconazole (Bao et al., 2017), meanwhile oral administration of posaconazole at the beginning of treatment is another choice (Clark et al., 2015). 


\section{Respiratory HCoVs}

Severe acute respiratory syndrome (SARS) and Middle East respiratory syndrome (MERS) are single-stranded, enveloped, positive-sense RNA viruses. Age and underlying disease are pivotal independent predictors of miscellaneous adverse outcomes in SARS (Chan et al., 2003). SARS cases were mainly seen in young healthy individuals, but patients over 60 years old have the highest mortality, whereas half of the cases of MERS$\mathrm{CoV}$ infections occurred in individuals over the age of 50 (Chan et al., 2003; Assiri et al., 2013). There is no difference in treatment options between the elderly and other age groups. Currently, the most commonly prescribed antiviral regimens are ribavirin, IFNs and lopinavir/ritonavir (Morgenstern et al., 2005; Al-Tawfiq et al., 2014; Omrani et al., 2014).

Ribavirin is a nucleoside analogue with broad-spectrum antiviral activity by inhibiting viral RNA synthesis and mRNA capping (von Grotthuss et al., 2003). The efficacy of ribavirin alone or in combination with IFN- $\beta$ for the treatment of SARS is inconsistent and controversial (Chu et al., 2004; Leong et al., 2004), and Canada announced a ban on ribavirin for the treatment of SARS due to the reported side effects and inadequate efficacy (Chiou et al., 2005). Lopinavir and ritonavir are protease inhibitors that may inhibit the 3C-like protease of MERS, they improve clinical outcome compared with ribavirin alone in SARS patients (Chan et al., 2006; Stockman et al., 2006). There are still no commercial vaccines available against MERS-CoV (Hart et al., 2014). Multiple vaccine candidates targeting the $S$ protein, which is responsible for viral entry, have been developed, including subunit vaccines (Wang et al., 2015; Tai et al., 2017) recombinant vector vaccines (Kim et al., 2014; Gilbert and Warimwe, 2017), and DNA vaccines (Al-Amri et al., 2017; Chi et al., 2017). Other agents, such as mycophenolic acid (MPA), which prevent replication of viral RNA, have showed strong inhibition activity against MERS-CoV in vitro studies (Hart et al., 2014). In addition, passive immunotherapy using human plasma was also applied in the treatment of SARS and MERS (Arabi et al., 2015; Mair-Jenkins et al., 2015). Generally, corticosteroids are widely used along with ribavirin during SARS outbreaks (Lee et al., 2004). A variety of other agents, including antiviral peptides, monoclonal antibodies, cellular or viral protease inhibitor may be promising agents for vitro and/or animal models (Ohnuma et al., 2013; Tao et al., 2014; Agrawal et al., 2016; Zumla et al., 2016). But the efficacy in patients with SARS and MERS needs further clinical validation. In in vitro experiments, IFN products were effective in inhibiting both SARS-CoV and MRES-CoV152 (Morgenstern et al., 2005; Chan et al., 2013). Meanwhile, although specific antivirals for MERS-CoV and SARS-CoV are developing, medication with repurposing potential, such as loperamide (de Wilde et al., 2014), chloroquine (Keyaerts et al., 2004), cyclophilins (Stamnes et al., 1992), kinase inhibitors (Dyall et al., 2014), may present as additional therapeutics for future coronaviruses.

\section{Influenza}

Influenza-related deaths gradually increase with increasing age (Yu et al., 2013). From 1979 to 2001, adults $\geq 65$ years old accounted for approximately $60 \%$ of influenza-related hospitalizations (Casey et al., 2010; Nicoll, 2010). Data from central and south America (Cheng et al., 2015), European Centre for Disease Prevention and Control (ECDC) - Surveillance and Communication Unit (2011), Africa (Cohen et al., 2018), and southeast Asia (Wong et al., 2006; Park et al., 2016; Ang et al., 2017) are consistent, reporting higher morbidity and mortality in old adults.

Due to doubts about the potency of influenza vaccines, the vaccination rate of influenza vaccine among the elderly is very low (Schmid et al., 2017). In addition, insufficient supply of vaccine and vaccine hesitancy also contribute to inadequate vaccination for the elderly.

Some standard-dose (SD) influenza vaccine studies among elderly have estimated benefits in preventing hospitalization and mortality due to pneumonia (Nichol et al., 2003; Nichol et al., 2007; Jansen et al., 2008). Meanwhile, the high-dose (HD) trivalent influenza vaccine (TIV) was $22 \%$ more effective than SD influenza vaccine at preventing probable influenza infections, and $22 \%$ more effective than SD influenza vaccine in preventing influenza hospital admission (Izurieta et al., 2015). Another retrospective cohort of U.S. veterans found that, in the 85-year-old group, there was a significant reduction in hospitalizations influenza and pneumonia associated with the HD TIV injection (Richardson et al., 2015). According to observational studies and RCTs, HD TIV (Wong et al., 2006; Park et al., 2016), MF-59-adjuvanted influenza vaccine appeared to have efficacy for clinical influenza (i.e., ILI) and serologically confirmed influenza in adults older than 60 years old (Govaert et al., 1994; Engler et al., 2008; Taylor et al., 2012; Van Buynder et al., 2013; Darvishian et al., 2017; Domnich et al., 2017; Shay et al., 2017). For the diagnosed Influenza, neuraminidase inhibitors (NAI), including oseltamivir (Dobson et al., 2015), zanamivir (Heneghan et al., 2014), and peramivir (2015), are effective against both influenza A and influenza B viruses.

\section{DISCUSSION}

We reviewed a number of newly developed agents systematically, with the purpose to weigh their relative advantages and limitations for utilization in the elderly population. According to the key advantages, we classified the above antibiotics into "not recommended, moderate recommended and recommend". For example, telavancin's better bioavailability, food-independent efficacy, and simple dosing regimens that support once daily administration, make it a potential therapy for the elderly with LRTIs.

As for nemonoxacin, all the above trials of this medicine enrolled patients over the age of 65 , while this age group had not been separated into a subgroup to test the safety and efficacy of certain antibiotics alone. But considering that the elderly accounts for the majority of the participants, we still recommended nemonoxacin as a first-line medication for LRTIs in elderly according to the key criteria we have formulated above. 
By contrast, zabofloxaxin has little potential for the treatment of LRTIs in elderly. Although it can be a potential therapy for COPD patients with moderate-severity exacerbations, zabofloxacin is ineffective against common non-community acquired pathogens such as aeruginosa and A. baumannii. For elderly patients in long-term care centers or over-hospitalized patients with underlying diseases such as cystic fibrosis, it should be noted that zabofloxacin may not be applicable (Han et al., 2013). In addition, the safety and efficacy of intravenous formulation of zabofloxacin are still unclear. Moreover, zabofloxacin has not been approved by the Food and Drug Administration (FDA) for CAP treatment.

As for telavancin, it is a novel semi-synthetic lipoglycopeptides that is active against multidrug resistant (MDR) staphylococci, enterococci, and streptococci. Telavancin's better bioavailability, food-independent efficacy, and simple dosing regimens that support once daily administration, make it a potential therapy for old people with LRTIs.

Omadacycline was a novel once-daily aminomethylcycline antibiotic, and became the second tetracycline antibiotic approved by the FDA in 2018. Despite all the obvious advantages of omadacycline, enough attention should be given to the drawbacks for cardiac electrophysiology, namely, changes in heart rate (HR) and QT interval (Duraes and Sousa, 2019).

As a member of macrolides, solithromycin has little potential for the treatment of LRTIs in elderly. Based on the fact that solithromycin is an inhibitor of CYP3A4, the same caution should be used when co-administering solithromycin with agents that have demonstrated interaction with the precedent macrolides. Solithromycin appears to affect plasma concentrations of digoxin and warfarin, probably due to its interaction with P-glycoprotein and CYP3A4, leading to bradydysrhythmias and increased bleeding risk in elderly (Still et al., 2011). Sleep disorders and related medications, such as benzodiazepines, are commonly used in elderly, and these medications are mainly metabolized by CYP3A 4 and induce side effects or attenuate therapeutic effects (Kasper and Resinger, 2001). Therefore, the combination of the two categories of agents should be avoided, and if it's unavoidable, the dose of benzodiazepines should be reduced.

In 2010, ceftaroline was approved by the FDA and European Medicines Agency (EMA) for the treatment of CAP. Ceftaroline is only recommended in the intravenous formation in a hospitalized setting for elderly CAP patients with creatinine clearance of $\geq>30 \mathrm{~mL} / \mathrm{min}$, no QT prolongation history, and PORT risk classes III-IV. First of all, the lack of an oral formulation for ceftaroline is a limiting property for its use in the hospital setting. Secondly, ceftaroline has weak antibacterial activity against E. faecium, VRE, ESBL-E, and P. aeruginosa (Kiang et al., 2015), which are common pathogens found in HAP patients with comorbidities or long-term nursing homes and are frequently treated with antibiotics. In addition, although the AEs are mostly mild, in FOCUS 1, 1.4\% of ceftaroline patients and $1.0 \%$ of ceftriaxone patients developed QTcB prolongation, both of which were $>500 \mathrm{~ms}$, with the elongation of $\geq>60 \mathrm{~ms}$ compared with the baseline.
For another Cephalosporins, ceftobiprole is suitable for patients with suspected pneumonia caused by $M R S A$, Enterobacteriaceae or $P$. aeruginosa, especially for patients who live in nursing homes for a long time, but more data in elderly population are required for further recommendation. Ceftobiprole, q8h, IV limits the daily activities of the elderly. For old people with malnutrition and impaired cognitive function, the risk of sarcopenia, delirium, pressure ulcer, and sputum may be increased. A survey of about one-third of clinical trial centers found that a large portion of the data in these centers were unreliable or unverifiable (Abbas et al., 2017; Jean et al., 2017), thus the FDA has requested more information and recommended additional clinical studies before ceftobiprole is approved for cSSSI and pneumonia.

We have summarized the key advantages of lefamulin in treatment of LRTIs above. In our opinion, lefamulin should be recommended as a promising agent for LRTIs in elderly, and attention must be paid to its interaction with other medicines, such as azole antifungals (Paukner et al., 2019) and midazolam (File et al., 2019) at the same time. Beyond that, it takes $12 \mathrm{~h}$ to the intravenous use of lefamulin, which more or less limits the activity of elderly patients and increases the possibility of convulsions.

Until now, there is insufficient evidence to support tedizolid as an ideal antibiotic therapy for LRTIs in elderly at present. Tedizolid is still not a FDA/EMA-approved antibiotic for the treatment of LRTIs, but it does bring hope to patients suffering liver and kidney organ failure, especially for LRTIs associated with linezolid-resistant Gram-positive pathogens. Although the phase 3 trial (NCT02019420) of tedizolid for HAP has not yet yielded results, tedizolid brings hope to old patients suffering renal or hepatic failure, especially with linezolidresistant Gram-positive pathogens pneumonia (Flanagan et al., 2018).

\section{CONCLUSIONS}

Despite noteworthy decreases in the number of deaths due to LRTIs, there remains an urgent need to make efforts to reduce the burden of disease in the elderly, especially for those with physical decline, mechanical ventilation, immunosuppression, frailty, dementia, and comorbidities. Although there are no pharmacotherapy and guidelines specifically for old patients with LRTIs, pharmacists and clinicians will need to weigh their various advantages and limitations based on the typical challenges that are faced by the elderly before choosing the optimal pharmacotherapy.

\section{AUTHOR CONTRIBUTIONS}

YL and BD conceived and designed the project. YL, YZ, WZ has contributed significantly to the submitted work and wrote the first draft. YL, XL, and FH revised the manuscript. All authors read and approved the final manuscript. 


\section{REFERENCES}

(2015). Peramivir (Rapivab): an IV neuraminidase inhibitor for treatment of influenza. Med. Lett. Drugs Ther. 57 (1461), 17-19.

(2019). Omadacycline (Nuzyra)-a new tetracycline antibiotic. JAMA 322 (5), 457-458. doi: 10.1001/jama.2019.8199

3Rd, H. E., Golden, M., Jamieson, B. D., Dixon, P. B., Harbison, H. S., Lowens, S., et al. (2015). A phase 2 trial of oral solithromycin $1200 \mathrm{mg}$ or $1000 \mathrm{mg}$ as single-dose oral therapy for uncomplicated gonorrhea. Clin. Infect. Dis. 61 (7), 1043. doi: $10.1093 / \mathrm{cid} / \mathrm{civ} 478$

Abbas, M., Paul, M., and Huttner, A. (2017). New and improved? A review of novel antibiotics for gram-positive bacteria. Clin. Microbiol. Infect. Official Pub. Eur. Soc. Clin. Microbiol. Infect. Dis. 23 (10), S1198743X17303294. doi: 10.1016/j. cmi.2017.06.010

Agrawal, A. S., Ying, T., Tao, X., Garron, T., Algaissi, A., Wang, Y., et al. (2016). Passive transfer of a germline-like neutralizing human monoclonal antibody protects transgenic mice against lethal middle east respiratory syndrome coronavirus infection. Sci. Rep. 6, 31629. doi: 10.1038/srep31629

Al-Amri, S. S., Abbas, A. T., Siddiq, L. A., Alghamdi, A., Sanki, M. A., Al-Muhanna, M. K., et al. (2017). Immunogenicity of candidate MERS-CoV DNA vaccines based on the spike protein. Sci. Rep. 7, 44875. doi: 10.1038/srep44875

Al-Tawfiq, J. A., Momattin, H., Dib, J., and Memish, Z. A. (2014). Ribavirin and interferon therapy in patients infected with the middle east respiratory syndrome coronavirus: an observational study. Int. J. Infect. Dis. 20, 42-46. doi: 10.1016/j.ijid.2013.12.003

Al Jalali, V., and Zeitlinger, M. (2018). Clinical pharmacokinetics and pharmacodynamics of telavancin compared with the other glycopeptides. Clin. Pharmacokinet. 57 (7), 797-816. doi: 10.1007/s40262-017-0623-4

Ales, T., Craig, R., Igor, G., Petr, H., Anna, S., Waleria, H., et al. (2013). Clinical and economic burden of community-acquired pneumonia among adults in the Czech Republic, Hungary, Poland and Slovakia. Plos One 8 (8), e71375. doi: 10.1371/journal.pone.0071375

Alldred, D. P., Standage, C., Zermansky, A. G., Barber, N. D., Raynor, D. K., and Petty, D. R. (2010). The recording of drug sensitivities for older people living in care homes. Br. J. Clin. Pharmacol. 69 (5), 553-557. doi: 10.1111/j.1365-2125.2010.03631.x

Ang, L. W., Yap, J., Lee, V., Chng, W. Q., Jaufeerally, F. R., Lam, C. S. P., et al. (2017). Influenza-associated hospitalizations for cardiovascular diseases in the tropics. Am. J. Epidemiol. 186 (2), 202-209. doi: 10.1093/aje/kwx001

Arabi, Y., Balkhy, H., Hajeer, A. H., Bouchama, A., Hayden, F. G., Al-Omari, A., et al. (2015). Feasibility, safety, clinical, and laboratory effects of convalescent plasma therapy for patients with middle east respiratory syndrome coronavirus infection: a study protocol. Springerplus 4, 709. doi: 10.1186/s40064-015-1490-9

Arnold, F. W., Summersgill, J. T., and Ramirez, J. A. (2016). Role of atypical pathogens in the etiology of community-acquired pneumonia. Semin Respir. Crit. Care Med. 37 (6), 819-828. doi: 10.1055/s-0036-1592121

Asche, C., McAdam-Marx, C., Seal, B., Crookston, B., and Mullins, C. D. (2008). Treatment costs associated with community-acquired pneumonia by community level of antimicrobial resistance. J. Antimicrob. Chemother. 61 (5), 1162-1168. doi: 10.1093/jac/dkn073

Assiri, A., Al-Tawfiq, J. A., Al-Rabeeah, A. A., Al-Rabiah, F. A., Al-Hajjar, S., Al-Barrak, A., et al. (2013). Epidemiological, demographic, and clinical characteristics of 47 cases of middle east respiratory syndrome coronavirus disease from Saudi Arabia: a descriptive study. Lancet Infect. Dis. 13 (9), $752-$ 761. doi: 10.1016/S1473-3099(13)70204-4

Awad, S. S., Rodriguez, A. H., Chuang, Y. C., Marjanek, Z., Pareigis, A. J., Reis, G., et al. (2014). A phase 3 randomized double-blind comparison of ceftobiprole medocaril versus ceftazidime plus linezolid for the treatment of hospitalacquired pneumonia. Clin. Infect. Dis. 59 (1), 51-61. doi: 10.1093/cid/ciu219

Baddour, L. M., Yu, V. L., Klugman, K. P., Feldman, C., Ortqvist, A., Rello, J., et al. (2004). Combination antibiotic therapy lowers mortality among severely ill patients with pneumococcal bacteremia. Am. J. Respir. Crit. Care Med. 170 (4), 440-444. doi: 10.1164/rccm.200311-1578OC

Bao, Z., Chen, H., Zhou, M., Shi, G., Li, Q., and Wan, H. (2017). Invasive pulmonary aspergillosis in patients with chronic obstructive pulmonary disease: a case report and review of the literature. Oncotarget 8 (23), 38069-38074. doi: 10.18632/oncotarget.16971
Barrera, C. M., Mykietiuk, A., Metev, H., Nitu, M. F., Karimjee, N., Doreski, P. A., et al. (2016). Efficacy and safety of oral solithromycin versus oral moxifloxacin for treatment of community-acquired bacterial pneumonia: a global, double-blind, multicentre, randomised, active-controlled, non-inferiority trial (SOLITAIRE-ORAL). Lancet Infect. Dis. 16 (4), 421-430. doi: 10.1016/ S1473-3099(16)00017-7

Barriere, S. L. (2014). The ATTAIN trials: efficacy and safety of telavancin compared with vancomycin for the treatment of hospital-acquired and ventilator-associated bacterial pneumonia. Future Microbiol. 9 (3), 281-289. doi: $10.2217 / \mathrm{fmb} .14 .4$

Bassetti, M., Vena, A., Croxatto, A., Righi, E., and Guery, B. (2018). How to manage Pseudomonas aeruginosa infections. Drugs Context 7, 212527. doi: 10.7573/ dic. 212527

Battaglia, S., Cardillo, I., Lavorini, F., Spatafora, M., and Scichilone, N. (2015). Erratum to: safety considerations of inhaled corticosteroids in the elderly. Drugs Aging 32 (12), 1067-1076. doi: 10.1007/s40266-015-0320-7

Bernardo, K., Pakulat, N., Fleer, S., Schnaith, A., Utermohlen, O., Krut, O., et al. (2004). Subinhibitory concentrations of linezolid reduce Staphylococcus aureus virulence factor expression. Antimicrob. Agents Chemother. 48 (2), $546-$ 555. doi: 10.1128/AAC.48.2.546-555.2004

Blanchard, E., Gabriel, F., Jeanne-Leroyer, C., Servant, V., and Dumas, P. Y. (2018). [Invasive pulmonary aspergillosis]. Rev. Mal. Respir. 35 (2), 171-187. doi: 10.1016/j.rmr.2018.01.002

Blazquez Garrido, R. M., Espinosa Parra, F. J., Alemany Frances, L., Ramos Guevara, R. M., Sanchez-Nieto, J. M., Segovia Hernandez, M., et al. (2005). Antimicrobial chemotherapy for Legionnaires disease: levofloxacin versus macrolides. Clin. Infect. Dis. 40 (6), 800-806. doi: 10.1086/428049

Boyd, A. R., and Orihuela, C. J. (2011). Dysregulated inflammation as a risk factor for pneumonia in the elderly. Aging Dis. 2 (6), 487-500.

Bradley, J. S. (2014). Which antibiotic for resistant gram-positives, and why? J. Infect. 68 Suppl 1, S63-S75. doi: 10.1016/j.jinf.2013.09.016

Brown, S. D., and Traczewski, M. M. (2010). Comparative in vitro antimicrobial activities of torezolid (TR-700), the active moiety of a new oxazolidinone, torezolid phosphate (TR-701), determination of tentative disk diffusion interpretive criteria, and quality control ranges. Antimicrob. Agents Chemother. 54 (5), 2063-2069. doi: 10.1128/AAC.01569-09

Cao, B., Qu, J. X., Yin, Y. D., and Eldere, J. V. (2017). Overview of antimicrobial options for mycoplasma pneumoniae pneumonia: focus on macrolide resistance. Clin. Respir. J. 11 (4), 419-429. doi: 10.1111/crj.12379

Cao, G. Y., Zhang, J., Zhang, Y. Y., Guo, B. N., Yu, J. C., Wu, X. J., et al. (2014). Safety, tolerability, and pharmacokinetics of intravenous nemonoxacin in healthy chinese volunteers. Antimicrob. Agents Chemother. 58 (10), 6116-6121. doi: 10.1128/AAC.02972-14

Casey, C. G., Lyss, S. C., Gunn, R. A., Rutledge, T. F., Weatherwax, D. W., and Meadows, D. G. (2010). Estimates of deaths associated with seasonal influenza - United States, 1976-2007. MMWR Morb. Mortal Wkly Rep. 59 (33), 1057-1062.

Casqueiro, J., Casqueiro, J., and Alves, C. (2012). Infections in patients with diabetes mellitus: a review of pathogenesis. Indian J. Endocrinol. Metab. 16 Suppl 1, S27-S36. doi: 10.4103/2230-8210.94253

Chan, J. F., Chan, K. H., Kao, R. Y., To, K. K., Zheng, B. J., Li, C. P., et al. (2013). Broad-spectrum antivirals for the emerging middle east respiratory syndrome coronavirus. J. Infect. 67 (6), 606-616. doi: 10.1016/j.jinf.2013.09.029

Chan, K. S., Zheng, J. P., Mok, Y. W., Li, Y. M., Liu, Y. N., Chu, C. M., et al. (2003). SARS: prognosis, outcome and sequelae. Respirology 8 Suppl, S36-S40. doi: 10.1046/j.1440-1843.2003.00522.x

Chan, P. K., Tang, J. W., and Hui, D. S. (2006). SARS: clinical presentation, transmission, pathogenesis and treatment options. Clin. Sci. (Lond.) 110 (2), 193-204. doi: 10.1042/CS20050188

Chang, S. P., Lee, H. Z., Lai, C. C., and Tang, H. J. (2019). The efficacy and safety of nemonoxacin compared with levofloxacin in the treatment of communityacquired pneumonia: a systemic review and meta-analysis of randomized controlled trials. Infect. Drug Resist. Volume 12, 433-438. doi: 10.2147/IDR. S193233

Chen, M., Xu, Y., Hong, N., Yang, Y., Lei, W., Du, L., et al. (2018). Epidemiology of fungal infections in China. Front. Med. 12 (1), 58-75. doi: 10.1007/ s11684-017-0601-0 
Cheng, P. Y., Palekar, R., Azziz-Baumgartner, E., Iuliano, D., Alencar, A. P., Bresee, J., et al. (2015). Burden of influenza-associated deaths in the Americas, 2002-2008. Influenza Other Respir. Viruses 9 Suppl 1, 13-21. doi: 10.1111/irv.12317

Chi, H., Zheng, X., Wang, X., Wang, C., Wang, H., Gai, W., et al. (2017). DNA vaccine encoding middle east respiratory syndrome coronavirus S1 protein induces protective immune responses in mice. Vaccine 35 (16), 2069-2075. doi: 10.1016/j.vaccine.2017.02.063

Chiou, H. E., Liu, C. L., Buttrey, M. J., Kuo, H. P., Liu, H. W., Kuo, H. T., et al. (2005). Adverse effects of ribavirin and outcome in severe acute respiratory syndrome: experience in two medical centers. Chest 128 (1), 263-272. doi: 10.1378/chest.128.1.263

Choi, J. Y., Kim, S. W., Yoon, S. J., Kang, M. G., Kim, K. I., and Kim, C. H. (2018). Impact of frailty on do-not-resuscitate orders and healthcare transitions among elderly Koreans with pneumonia. Clin. Interv. Aging 13, 2237-2245. doi: 10.2147/CIA.S181400

Chu, C. M., Cheng, V. C., Hung, I. F., Wong, M. M., Chan, K. H., Chan, K. S., et al. (2004). Role of lopinavir/ritonavir in the treatment of SARS: initial virological and clinical findings. Thorax 59 (3), 252-256. doi: 10.1136/thorax.2003.012658

Clark, N. M., Grim, S. A., and Lynch, J. P. (2015). Posaconazole: use in the prophylaxis and treatment of fungal infections. Semin Respir. Crit. Care Med. 36 (5), 767-785. doi: 10.1055/s-0035-1562902

Cohen, C., Walaza, S., Treurnicht, F. K., McMorrow, M., Madhi, S. A., McAnerney, J. M., et al. (2018). In- and out-of-hospital mortality associated with seasonal and pandemic influenza and respiratory syncytial virus in South Africa, 20092013. Clin. Infect. Dis. 66 (1), 95-103. doi: 10.1093/cid/cix740

Cooper, E. C., Curtis, N., Cranswick, N., and Gwee, A. (2014). Pristinamycin: old drug, new tricks? J. Antimicrob. Chemother. 69 (9), 2319-2325. doi: 10.1093/ $\mathrm{jac} / \mathrm{dku} 167$

Curcio, D. (2014). Multidrug-resistant gram-negative bacterial infections: are you ready for the challenge? Curr. Clin. Pharmacol. 9 (1), 27-38. doi: $10.2174 / 15748847113089990062$

Darpo, B., Sager, P. T., Fernandes, P., Jamieson, B. D., Keedy, K., Zhou, M., et al. (2017a). Solithromycin, a novel macrolide, does not prolong cardiac repolarization: a randomized, three-way crossover study in healthy subjects. J. Antimicrob. Chemother. 72 (2), 515. doi: 10.1093/jac/dkw428

Darpo, B., Sager, P. T., Fernandes, P., Jamieson, B. D., Keedy, K., Zhou, M., et al. (2017b). Solithromycin, a novel macrolide, does not prolong cardiac repolarization: a randomized, three-way crossover study in healthy subjects. J. Antimicrob. Chemother. 72 (2), 515-521. doi: 10.1093/jac/dkw428

Darvishian, M., van den Heuvel, E. R., Bissielo, A., Castilla, J., Cohen, C., Englund, H., et al. (2017). Effectiveness of seasonal influenza vaccination in community-dwelling elderly people: an individual participant data metaanalysis of test-negative design case-control studies. Lancet Respir. Med. 5 (3), 200-211. doi: 10.1016/S2213-2600(17)30043-7

Das, B., Sarkar, C., Das, D., Gupta, A., Kalra, A., and Sahni, S. (2017). Telavancin: a novel semisynthetic lipoglycopeptide agent to counter the challenge of resistant Gram-positive pathogens. Ther. Adv. Infect. Dis. 4 (2), 49-73. doi: $10.1177 / 2049936117690501$

de Groot, R. C. A., Meyer Sauteur, P. M., Unger, W. W. J., and van Rossum, A. M. C. (2017). Things that could be Mycoplasma pneumoniae. J. Infect. 74 Suppl 1, S95-s100. doi: 10.1016/S0163-4453(17)30198-6

de Wilde, A. H., Jochmans, D., Posthuma, C. C., Zevenhoven-Dobbe, J. C., van Nieuwkoop, S., Bestebroer, T. M., et al. (2014). Screening of an FDA-approved compound library identifies four small-molecule inhibitors of Middle East respiratory syndrome coronavirus replication in cell culture. Antimicrob. Agents Chemother. 58 (8), 4875-4884. doi: 10.1128/AAC.03011-14

Denning, D. W., Cadranel, J., Beigelman-Aubry, C., Ader, F., Chakrabarti, A., Blot, S., et al. (2016). Chronic pulmonary aspergillosis: rationale and clinical guidelines for diagnosis and management. Eur. Respir. J. 47 (1), 45-68. doi: 10.1183/13993003.00583-2015

Ding, C., Yang, Z., Wang, J., Liu, X., Cao, Y., Pan, Y., et al. (2016). Prevalence of Pseudomonas aeruginosa and antimicrobial-resistant Pseudomonas aeruginosa in patients with pneumonia in mainland China: a systematic review and metaanalysis. Int. J. Infect. Dis. 49, 119-128. doi: 10.1016/j.ijid.2016.06.014

Dobson, J., Whitley, R. J., Pocock, S., and Monto, A. S. (2015). Oseltamivir treatment for influenza in adults: a meta-analysis of randomised controlled trials. Lancet 385 (9979), 1729-1737. doi: 10.1016/S0140-6736(14)62449-1
Domnich, A., Arata, L., Amicizia, D., Puig-Barbera, J., Gasparini, R., and Panatto, D. (2017). Effectiveness of MF59-adjuvanted seasonal influenza vaccine in the elderly: a systematic review and meta-analysis. Vaccine 35 (4), 513-520. doi: 10.1016/j.vaccine.2016.12.011

Dougherty, J. A., Sucher, A. J., Chahine, E. B., and Shihadeh, K. C. (2019). Omadacycline: A New Tetracycline Antibiotic. Ann. Pharmacother. 53 (5), 486-500. doi: 10.1177/1060028018818094

Duncan, L. R., Sader, H. S., Smart, J. I., Flamm, R. K., and Mendes, R. E. (2017). Telavancin activity in vitro tested against a worldwide collection of Gram-positive clinical isolates (2014). J. Glob. Antimicrob. Resist. 10, S2213716517301248. doi: 10.1016/j.jgar.2017.03.018

Duraes, F., and Sousa, E. (2019). Omadacycline: a newly approved antibacterial from the class of tetracyclines. Pharmaceuticals (Basel) 12 (2), E63. doi: 10.3390/ph12020063

Dyall, J., Coleman, C. M., Hart, B. J., Venkataraman, T., Holbrook, M. R., Kindrachuk, J., et al. (2014). Repurposing of clinically developed drugs for treatment of middle east respiratory syndrome coronavirus infection. Antimicrob. Agents Chemother. 58 (8), 4885-4893. doi: 10.1128/AAC.03036-14

Edelstein, P. H., Edelstein, M. A., Lehr, K. H., and Ren, J. (1996). In-vitro activity of levofloxacin against clinical isolates of Legionella spp, its pharmacokinetics in guinea pigs, and use in experimental Legionella pneumophila pneumonia. J. Antimicrob. Chemother. 37 (1), 117-126. doi: 10.1093/jac/37.1.117

Engler, R. J., Nelson, M. R., Klote, M. M., VanRaden, M. J., Huang, C. Y., Cox, N. J., et al. (2008). Half- vs full-dose trivalent inactivated influenza vaccine (20042005): age, dose, and sex effects on immune responses. Arch. Intern. Med. 168 (22), 2405-2414. doi: 10.1001/archinternmed.2008.513

European Centre for Disease Prevention and Control (ECDC) - Surveillance and Communication Unit. (2011). European centre for disease prevention and control publishes annual epidemiological report 2011. Eur. Surveill 16 (45). doi: 10.1186/1475-2875-10-340

Falco, V., Burgos, J., and Almirante, B. (2018). Ceftobiprole medocaril for the treatment of community-acquired pneumonia. Expert Opin. Pharmacother. 19 (13), 1503-1509. doi: 10.1080/14656566.2018.1516749

Farrell, D. J., Flamm, R. K., Sader, H. S., and Jones, R. N. (2014). Ceftobiprole activity against over 60,000 clinical bacterial pathogens isolated in Europe, Turkey, and Israel from 2005 to 2010. Antimicrob. Agents Chemother. 58 (7), 3882-3888. doi: 10.1128/AAC.02465-14

File, T. M., Jr., Goldberg, L., Das, A., Sweeney, C., Saviski, J., Gelone, S. P., et al. (2019). Efficacy and safety of IV-to-oral lefamulin, a pleuromutilin antibiotic, for treatment of community-acquired bacterial pneumonia: the phase 3 LEAP 1 trial. Clin. Infect. Dis. doi: 10.1093/cid/ciz090

File, T. M., Jr., Low, D. E., Eckburg, P. B., Talbot, G. H., Friedland, H. D., Lee, J., et al. (2011). FOCUS 1: a randomized, double-blinded, multicentre, Phase III trial of the efficacy and safety of ceftaroline fosamil versus ceftriaxone in community-acquired pneumonia. J. Antimicrob. Chemother. 66 Suppl 3, iii19iii32. doi: 10.1093/jac/dkr096

File, T. M., Jr., Rewerska, B., Vucinic-Mihailovic, V., Gonong, J. R. V., Das, A. F., Keedy, K., et al. (2016). SOLITAIRE-IV: a randomized, double-blind, multicenter study comparing the efficacy and safety of intravenous-tooral solithromycin to intravenous-to-oral moxifloxacin for treatment of community-acquired bacterial pneumonia. Clin. Infect. Dis. 63 (8), 1007-1016. doi: $10.1093 / \mathrm{cid} /$ ciw490

Fine, M. J., Smith, M. A., Carson, C. A., Mutha, S. S., Sankey, S. S., Weissfeld, L. A., et al. (1996). Prognosis and outcomes of patients with community-acquired pneumonia. a meta-analysis. JAMA 275 (2), 134-141. doi: 10.1001/ jama.1996.03530260048030

Flanagan, S., Bartizal, K., Minassian, S. L., Fang, E., and Prokocimer, P. (2013). In vitro, in vivo, and clinical studies of tedizolid to assess the potential for peripheral or central monoamine oxidase interactions. Antimicrob. Agents Chemother. 57 (7), 3060-3066. doi: 10.1128/AAC.00431-13

Flanagan, S. D., Minassian, S. L., and Prokocimer, P. (2018). Pharmacokinetics, safety, and tolerability of tedizolid phosphate in elderly subjects. Clin. Pharmacol. Drug Dev. 7 (7), 788-794. doi: 10.1002/cpdd.426

Francois, B., Luyt, C. E., Stover, C. K., Brubaker, J. O., Chastre, J., and Jafri, H. S. (2017). New strategies targeting virulence factors of Staphylococcus aureus and Pseudomonas aeruginosa. Semin Respir. Crit. Care Med. 38 (3), 346-358. doi: $10.1055 / \mathrm{s}-0037-1602715$ 
Genne, D., Siegrist, H. H., Humair, L., Janin-Jaquat, B., and de Torrente, A. (1997). Clarithromycin versus amoxicillin-clavulanic acid in the treatment of community-acquired pneumonia. Eur. J. Clin. Microbiol. Infect. Dis. 16 (11), 783-788. doi: 10.1007/BF01700406

Gilbert, S. C., and Warimwe, G. M. (2017). Rapid development of vaccines against emerging pathogens: the replication-deficient simian adenovirus platform technology. Vaccine 35 (35 Pt A), 4461-4464. doi: 10.1016/j.vaccine.2017.04.085

Giske, C. G., Monnet, D. L., Otto, C., and Yehuda, C. (2008). Clinical and economic impact of common multidrug-resistant gram-negative bacilli. Antimicrob. Agents Chemother. 52 (3), 813. doi: 10.1128/AAC.01169-07

Gleason, P. P., Meehan, T. P., Fine, J. M., Galusha, D. H., and Fine, M. J. (1999). Associations between initial antimicrobial therapy and medical outcomes for hospitalized elderly patients with pneumonia. Arch. Intern. Med. 159 (21), 2562-2572. doi: 10.1001/archinte.159.21.2562

Govaert, T. M., Thijs, C. T., Masurel, N., Sprenger, M. J., Dinant, G. J., and Knottnerus, J. A. (1994). The efficacy of influenza vaccination in elderly individuals. A randomized double-blind placebo-controlled trial. JAMA 272 (21), 1661-1665. doi: 10.1001/jama.1994.03520210045030

Green, K., Mcgeer, A., Rudnick, W., Pong-Porter, S., Patel, S. N., and Low, D. E. (2014). In vitro activity of new Cephalosporins vs Streptococcus pneumoniae from the Canadian bacterial surveillance network: 2008-2011. Curr. Microbiol. 69 (5), 763-767. doi: 10.1007/s00284-014-0622-8

Han, H., Kim, S. E., Shin, K. H., Lim, C., Lim, K. S., Yu, K. S., et al. (2013). Comparison of pharmacokinetics between new quinolone antibiotics: the zabofloxacin hydrochloride capsule and the zabofloxacin aspartate tablet. Curr. Med. Res. Opin. 29 (10), 1349-1355. doi: 10.1185/03007995.2013.825591

Haranaga, S., Tateyama, M., Higa, F., Miyagi, K., Akamine, M., Azuma, M., et al. (2007). Intravenous ciprofloxacin versus erythromycin in the treatment of Legionella pneumonia. Intern. Med. 46 (7), 353-357. doi: 10.2169/ internalmedicine.46.6006

Hart, B. J., Dyall, J., Postnikova, E., Zhou, H., Kindrachuk, J., Johnson, R. F., et al. (2014). Interferon-beta and mycophenolic acid are potent inhibitors of middle east respiratory syndrome coronavirus in cell-based assays. J. Gen. Virol. 95 (Pt 3), 571-577. doi: 10.1099/vir.0.061911-0

Hassoun, A., Friedman, B., and Saravolatz, L. D. (2017). Telavancin in the recent hospital acquired and ventilator associated pneumonia (HAP/VAP) 2016 guidelines. Clin. Infect. Dis. 64 (11), 1633. doi: 10.1093/cid/cix272

Heneghan, C. J., Onakpoya, I., Thompson, M., Spencer, E. A., Jones, M., and Jefferson, T. (2014). Zanamivir for influenza in adults and children: systematic review of clinical study reports and summary of regulatory comments. BMJ 348, g2547. doi: 10.1136/bmj.g2547

Hodille, E., Delouere, L., Bouveyron, C., Meugnier, H., Bes, M., Tristan, A., et al. (2017). In vitro activity of ceftobiprole on 440 Staphylococcus aureus strains isolated from bronchopulmonary infections. Med. Mal. Infect. 47 (2), 152-157. doi: 10.1016/j.medmal.2016.10.004

Hook, E.W.3rd, Golden, M., Jamieson, B. D., Dixon, P. B., Harbison, H. S., Lowens, S., et al. (2015). A phase 2 trial of oral solithromycin $1200 \mathrm{mg}$ or 1000 mg as single-dose oral therapy for uncomplicated gonorrhea. Clin. Infect. Dis. 61 (7), 1043-1048. doi: 10.1093/cid/civ478

Horn, K. S., Danziger, L. H., Rodvold, K. A., and Glowacki, R. C. (2017). Pharmacokinetic drug evaluation of ceftobiprole for the treatment of MRSA. Expert Opin. Drug Metab. Toxicol. 13 (4), 463-472. doi: 10.1080/17425255.2017.1303481

Housman, S. T., Pope, J. S., Russomanno, J., Salerno, E., Shore, E., Kuti, J. L., et al. (2012). Pulmonary disposition of tedizolid following administration of once-daily oral 200-milligram tedizolid phosphate in healthy adult volunteers. Antimicrob. Agents Chemother. 56 (5), 2627-2634. doi: 10.1128/AAC.05354-11

Huang, D. B., File, T. M., Jr., Dryden, M., Corey, G. R., Torres, A., and Wilcox, M. H. (2018). Surveillance of iclaprim activity: In vitro susceptibility of grampositive pathogens collected from 2012 to 2014 from the United States, Asia Pacific, Latin American and Europe. Diagn. Microbiol. Infect. Dis. 90 (4), 329334. doi: 10.1016/j.diagmicrobio.2017.12.001

Huang, D. B., Hawser, S., Gemmell, C. G., and Sahm, D. F. (2017). In vitro activity of iclaprim against methicillin-resistant Staphylococcus aureus nonsusceptible to Daptomycin, Linezolid, or Vancomycin: a pilot study. Can. J. Infect. Dis. Med. Microbiol. 2017, 1-6. doi: 10.1155/2017/3948626

Huang, D. B., Magnet, S., De Angelis, S., Holland, T. L., File, T. M., Jr., Dryden, M., et al. (2019). Surveillance of iclaprim activity: in vitro susceptibility of gram-positive skin infection pathogens collected from 2015 to 2016 from North America and Europe. Diagn. Microbiol. Infect. Dis. 93 (2), 154-158. doi: 10.1016/j.diagmicrobio.2018.09.002

Izurieta, H. S., Thadani, N., and Shay, D. K. (2015). Corrections. Comparative effectiveness of high-dose versus standard-dose influenza vaccines in US residents aged 65 years and older from 2012 to 2013 using Medicare data: a retrospective cohort analysis. Lancet Infect. Dis. 15 (3), 263. doi: 10.1016/ S1473-3099(15)70070-8

James, S. L., Abate, D., Abate, K. H., Abay, S. M., Abbafati, C., Abbasi, N., et al. (2018). Global, regional, and national incidence, prevalence, and years lived with disability for 354 diseases and injuries for 195 countries and territories, 1990-2017: a systematic analysis for the Global Burden of Disease Study 2017. Lancet 392 (10159), 1789-1858. doi: 10.1016/s0140-6736(18)32279-7

Jansen, A. G., Sanders, E. A., Nichol, K. L., van Loon, A. M., Hoes, A. W., and Hak, E. (2008). Decline in influenza-associated mortality among Dutch elderly following the introduction of a nationwide vaccination program. Vaccine 26 (44), 5567-5574. doi: 10.1016/j.vaccine.2008.08.003

Jean, S. S., Hsueh, P. R., Lee, W. S., Chang, H. T., Chou, M. Y., Chen, I. S., et al. (2009). Nationwide surveillance of antimicrobial resistance among Haemophilus influenzae and Streptococcus pneumoniae in intensive care units in Taiwan. Eur. J. Clin. Microbiol. Infect. Dis. 28 (8), 1013-1017. doi: 10.1007/ s10096-009-0727-3

Jean, S. S., Lee, W. S., Yu, K. W., Liao, C. H., Hsu, C. W., Chang, F. Y., et al. (2017). Corrigendum to "Rates of susceptibility of carbapenems, ceftobiprole, and colistin against clinically important bacteria collected from intensive care units in 2007: results from the surveillance of multicenter antimicrobial resistance in Taiwan (SMART)". J. Microbiol. Immunol. Infect. 51(3), 423-424.

Jones, R. N., Sader, H. S., Moet, G. J., and Farrell, D. J. (2010). Declining antimicrobial susceptibility of Streptococcus pneumoniae in the United States: report from the SENTRY antimicrobial surveillance program (1998-2009). Diagn. Microbiol. Infect. Dis. 68 (3), 334-336. doi: 10.1016/j.diagmicrobio.2010.08.024

Justo, J. A., Mayer, S. M., Pai, M. P., Soriano, M. M., Danziger, L. H., Novak, R. M., et al. (2015). Pharmacokinetics of ceftaroline in normal body weight and obese (classes I, II, and III) healthy adult subjects. Antimicrob. Agents Chemother. 59 (7), 3956-3965. doi: 10.1128/AAC.00498-15

Kalil, A. C., Klompas, M., Haynatzki, G., and Rupp, M. E. (2013). Treatment of hospital-acquired pneumonia with linezolid or vancomycin: a systematic review and meta-analysis. BMJ Open 3 (10), e003912. doi: 10.1136/ bmjopen-2013-003912

Kasper, S., and Resinger, E. (2001). Panic disorder: the place of benzodiazepines and selective serotonin reuptake inhibitors. Eur. Neuropsychopharmacol. 11 (4), 307-321. doi: 10.1016/S0924-977X(01)00100-6

Katzan, I. L., Cebul, R. D., Husak, S. H., Dawson, N. V., and Baker, D. W. (2003). The effect of pneumonia on mortality among patients hospitalized for acute stroke. Neurology 60 (4), 620-625. doi: 10.1212/01.WNL.0000046586.38284.60

Keyaerts, E., Vijgen, L., Maes, P., Neyts, J., and Van Ranst, M. (2004). In vitro inhibition of severe acute respiratory syndrome coronavirus by chloroquine. Biochem. Biophys. Res. Commun. 323 (1), 264-268. doi: 10.1016/j.bbrc.2004.08.085

Kiang, T. K., Wilby, K. J., and Ensom, M. H. (2015). A critical review on the clinical pharmacokinetics, pharmacodynamics, and clinical trials of ceftaroline. Clin. Pharmacokinet. 54 (9), 915-931. doi: 10.1007/s40262-015-0281-3

Kim, E., Okada, K., Kenniston, T., Raj, V. S., AlHajri, M. M., Farag, E. A., et al. (2014). Immunogenicity of an adenoviral-based middle east respiratory syndrome coronavirus vaccine in BALB/c mice. Vaccine 32 (45), 5975-5982. doi: 10.1016/j.vaccine.2014.08.058

Kocsis, B., Domokos, J., and Szabo, D. (2016). Chemical structure and pharmacokinetics of novel quinolone agents represented by avarofloxacin, delafloxacin, finafloxacin, zabofloxacin and nemonoxacin. Ann. Clin. Microbiol. Antimicrob. 15 (1), 34. doi: 10.1186/s12941-016-0150-4

Kollef, M. H., and Betthauser, K. D. (2019). New antibiotics for communityacquired pneumonia. Curr. Opin. Infect. Dis. 32 (2), 169-175. doi: 10.1097/ QCO.0000000000000526

Kornum, J. B., Thomsen, R. W., Riis, A., Lervang, H. H., Schonheyder, H. C., and Sorensen, H. T. (2007). Type 2 diabetes and pneumonia outcomes: a population-based cohort study. Diabetes Care 30 (9), 2251-2257. doi: 10.2337/ dc06-2417

Kresken, M., Korber-Irrgang, B., Lauffer, J., Decker-Burgard, S., and Davies, T. (2011). In vitro activities of ceftobiprole combined with amikacin or 
levofloxacin against Pseudomonas aeruginosa: evidence of a synergistic effect using time-kill methodology. Int. J. Antimicrob. Agents 38 (1), 70-75. doi: 10.1016/j.ijantimicag.2011.01.028

Kuo, S. C., Chen, P. C., Shiau, Y. R., Wang, H. Y., Lai, J. F. S., Huang, W., et al. (2014). Levofloxacin-resistant haemophilus influenzae, Taiwan, 2004-2010. Emerg. Infect. Dis. 20 (8), 1386-1390. doi: 10.3201/eid2008.140341

Kwon, A. R., Min, Y. H., Ryu, J. M., Choi, D. R., Shim, M. J., and Choi, E. C. (2006). In vitro and in vivo activities of DW-224a, a novel fluoroquinolone antibiotic agent. J. Antimicrob. Chemother. 58 (3), 684-688. doi: 10.1093/jac/dkl304

Lau, Y. J., Hsueh, P. R., Liu, Y. C., Shyr, J. M., Huang, W. K., Teng, L. J., et al. (2006). Comparison of in vitro activities of tigecycline with other antimicrobial agents against Streptococcus pneumoniae, Haemophilus influenzae, and Moraxella catarrhalis in Taiwan. Microb. Drug Resist. 12 (2), 130-135. doi: 10.1089/ mdr.2006.12.130

Laue, H., Weiss, L., Bernardi, A., Hawser, S., Lociuro, S., and Islam, K. (2007). In vitro activity of the novel diaminopyrimidine, iclaprim, in combination with folate inhibitors and other antimicrobials with different mechanisms of action. J. Antimicrob. Chemother. 60 (6), 1391-1394. doi: 10.1093/jac/dkm409

Lee, N., Allen Chan, K. C., Hui, D. S., Ng, E. K., Wu, A., Chiu, R. W., et al. (2004). Effects of early corticosteroid treatment on plasma SARS-associated Coronavirus RNA concentrations in adult patients. J. Clin. Virol. 31 (4), 304309. doi: 10.1016/j.jcv.2004.07.006

Leong, H. N., Ang, B., Earnest, A., Teoh, C., Xu, W., and Leo, Y. S. (2004). Investigational use of ribavirin in the treatment of severe acute respiratory syndrome, Singapore, 2003. Trop. Med. Int. Health 9 (8), 923-927. doi: $10.1111 / \mathrm{j} .1365-3156.2004 .01281 . \mathrm{x}$

Li, X. Z., Plesiat, P., and Nikaido, H. (2015). The challenge of efflux-mediated antibiotic resistance in gram-negative bacteria. Clin. Microbiol. Rev. 28 (2), 337-418. doi: 10.1128/CMR.00117-14

Li, Y., Fang, W., Jiang, W., Hagen, F., Liu, J., Zhang, L., et al. (2017). Cryptococcosis in patients with diabetes mellitus II in mainland China: 1993-2015. Mycoses 60 (11), 706-713. doi: 10.1111/myc.12645

Liang, W., Chen, Y. C., Cao, Y. R., Liu, X. F., Huang, J., Hu, J. L., et al. (2013). Pharmacokinetics and pharmacodynamics of nemonoxacin against Streptococcus pneumoniae in an in vitro infection model. Antimicrob. Agents Chemother. 57 (7), 2942-2947. doi: 10.1128/AAC.01098-12

Limper, A. H., Knox, K. S., Sarosi, G. A., Ampel, N. M., Bennett, J. E., Catanzaro, A., et al. (2011). An official American Thoracic Society statement: treatment of fungal infections in adult pulmonary and critical care patients. Am. J. Respir. Crit. Care Med. 183 (1), 96-128. doi: 10.1164/rccm.2008-740ST

Lodise, T. P., Bidell, M. R., Flanagan, S. D., Zasowski, E. J., Minassian, S. L., and Prokocimer, P. (2016). Characterization of the haematological profile of 21 days of tedizolid in healthy subjects. J. Antimicrob. Chemother. 71 (9), 2553-2558. doi: 10.1093/jac/dkw206

Low, D. E., File, T. M., Jr., Eckburg, P. B., Talbot, G. H., David Friedland, H., Lee, J., et al. (2011). FOCUS 2: a randomized, double-blinded, multicentre, Phase III trial of the efficacy and safety of ceftaroline fosamil versus ceftriaxone in community-acquired pneumonia. J. Antimicrob. Chemother. 66 Suppl 3, iii33iii44. doi: $10.1093 / \mathrm{jac} / \mathrm{dkr} 097$

Luke, L., Li-Wen, C., Cheng-Yuan, T., Ching-Hung, H., Chung, D. T., Aronstein, W. S., et al. (2010). Dose escalation study of the safety, tolerability, and pharmacokinetics of nemonoxacin (TG-873870), a novel potent broadspectrum nonfluorinated quinolone, in healthy volunteers. Antimicrob. Agents Chemother. 54 (1), 405-410. doi: 10.1128/AAC.00682-09

Ma, H. M., Yu, R. H., and Woo, J. (2013). Recurrent hospitalisation with pneumonia is associated with higher 1-year mortality in frail older people. Intern. Med. J. 43 (11), 1210-1215. doi: 10.1111/imj.12258

Mair-Jenkins, J., Saavedra-Campos, M., Baillie, J. K., Cleary, P., Khaw, F. M., Lim, W. S., et al. (2015). The effectiveness of convalescent plasma and hyperimmune immunoglobulin for the treatment of severe acute respiratory infections of viral etiology: a systematic review and exploratory meta-analysis. J. Infect. Dis. 211 (1), 80-90. doi: 10.1093/infdis/jiu396

Mandell, L. A., Bartlett, J. G., Dowell, S. F., File, T. M., Jr., Musher, D. M., and Whitney, C. (2003). Update of practice guidelines for the management of community-acquired pneumonia in immunocompetent adults. Clin. Infect. Dis. 37 (11), 1405-1433. doi: 10.1086/380488

Marchello, C., Dale, A. P., Thai, T. N., Han, D. S., and Ebell, M. H. (2016). Prevalence of atypical pathogens in patients with cough and community-acquired pneumonia: a meta-analysis. Ann. Fam. Med. 14 (6), 552-566. doi: 10.1370/ afm.1993

Martinez, J. A., Horcajada, J. P., Almela, M., Marco, F., Soriano, A., Garcia, E., et al. (2003). Addition of a macrolide to a beta-lactam-based empirical antibiotic regimen is associated with lower in-hospital mortality for patients with bacteremic pneumococcal pneumonia. Clin. Infect. Dis. 36 (4), 389-395. doi: $10.1086 / 367541$

Mendes, R. E., Paukner, S., Doyle, T. B., Gelone, S. P., Flamm, R. K., and Sader, H. S. (2019). Low prevalence of gram-positive isolates showing elevated lefamulin MIC results during the SENTRY surveillance program for 2015-2016 and characterization of resistance mechanisms. Antimicrob. Agents Chemother. 63 (4), e02158-18. doi: 10.1128/AAC.02158-18

Miller, A. C. (1981). Erythromycin in legionnaires' disease: a re-appraisal. J. Antimicrob. Chemother. 7 (3), 217-222. doi: 10.1093/jac/7.3.217

Mohamed, N. M., Zakaria, A. S., Edward, E. A., and Abdel-Bary, A. (2019). In vitro and in vivo activity of Zabofloxacin and other Fluoroquinolones against MRSA isolates from a University Hospital in Egypt. Pol. J. Microbiol. 68 (1), 59-69. doi: 10.21307/pjm-2019-007

Morgenstern, B., Michaelis, M., Baer, P. C., Doerr, H. W., and Cinatl, J., Jr. (2005). Ribavirin and interferon-beta synergistically inhibit SARS-associated coronavirus replication in animal and human cell lines. Biochem. Biophys. Res. Commun. 326 (4), 905-908. doi: 10.1016/j.bbrc.2004.11.128

Mufson, M. A., and Stanek, R. J. (1999). Bacteremic pneumococcal pneumonia in one American City: a 20-year longitudinal study, 1978-1997. Am. J. Med. 107 (1a), 34s-43s. doi: 10.1016/S0002-9343(99)00098-4

Mykietiuk, A., Carratala, J., Fernandez-Sabe, N., Dorca, J., Verdaguer, R., Manresa, F., et al. (2005). Clinical outcomes for hospitalized patients with Legionella pneumonia in the antigenuria era: the influence of levofloxacin therapy. Clin. Infect. Dis. 40 (6), 794-799. doi: 10.1086/428059

Nespoulous, L., Matei, I., Charissoux, A., Bedane, C., and Assikar, S. (2018). Symmetrical drug-related intertriginous and flexural exanthema (SDRIFE) associated with pristinamycin, secnidazole, and nefopam, with a review of the literature. Contact Dermat. 79 (6), 378-380. doi: 10.1111/cod.13084

Nichol, K. L., Nordin, J., Mullooly, J., Lask, R., Fillbrandt, K., and Iwane, M. (2003). Influenza vaccination and reduction in hospitalizations for cardiac disease and stroke among the elderly. N. Engl. J. Med. 348 (14), 1322-1332. doi: 10.1056/ NEJMoa025028

Nichol, K. L., Nordin, J. D., Nelson, D. B., Mullooly, J. P., and Hak, E. (2007). Effectiveness of influenza vaccine in the community-dwelling elderly. N. Engl. J. Med. 357 (14), 1373-1381. doi: 10.1056/NEJMoa070844

Nicholson, S. C., Welte, T., File, T. M., Jr., Strauss, R. S., Michiels, B., Kaul, P., et al. (2012). A randomised, double-blind trial comparing ceftobiprole medocaril with ceftriaxone with or without linezolid for the treatment of patients with community-acquired pneumonia requiring hospitalisation. Int. J. Antimicrob. Agents 39 (3), 240-246. doi: 10.1016/j.ijantimicag.2011.11.005

Nicoll, A. (2010). Pandemic risk prevention in European countries: role of the ECDC in preparing for pandemics. Development and experience with a national selfassessment procedure, 2005-2008. Bundesgesundheitsblatt Gesundheitsforschung Gesundheitsschutz 53 (12), 1267-1275. doi: 10.1007/s00103-010-1163-3

Ocheretyaner, E. R., and Park, T. E. (2018). Delafloxacin: a novel fluoroquinolone with activity against methicillin-resistant Staphylococcus aureus (MRSA) and Pseudomonas aeruginosa. Expert Rev. Anti Infect. Ther. 16 (7), 523-530. doi: $10.1080 / 14787210.2018 .1489721$

Ohnuma, K., Haagmans, B. L., Hatano, R., Raj, V. S., Mou, H., Iwata, S., et al. (2013). Inhibition of middle east respiratory syndrome coronavirus infection by anti-CD26 monoclonal antibody. J. Virol. 87 (24), 13892-13899. doi: 10.1128/JVI.02448-13

Omrani, A. S., Saad, M. M., Baig, K., Bahloul, A., Abdul-Matin, M., Alaidaroos, A. Y., et al. (2014). Ribavirin and interferon alfa-2a for severe middle east respiratory syndrome coronavirus infection: a retrospective cohort study. Lancet Infect. Dis. 14 (11), 1090-1095. doi: 10.1016/S1473-3099(14)70920-X

Ortiz-Ruiz, G., Vetter, N., Isaacs, R., Carides, A., Woods, G. L., and Friedland, I. (2004). Ertapenem versus ceftriaxone for the treatment of community-acquired pneumonia in adults: combined analysis of two multicentre randomized, double-blind studies. J. Antimicrob. Chemother. 53 Suppl 2, ii59-ii66. doi: 10.1093/jac/dkh207

Park, H. S., Jung, S. J., Kwak, J. H., Choi, D. R., and Choi, E. C. (2010). DNA gyrase and topoisomerase IV are dual targets of zabofloxacin in Streptococcus 
pneumoniae. Int. J. Antimicrob. Agents 36 (1), 97-98. doi: 10.1016/j. ijantimicag.2010.02.022

Park, H. S., Kim, H. J., Seol, M. J., Choi, D. R., Choi, E. C., and Kwak, J. H. (2006). In vitro and in vivo antibacterial activities of DW-224a, a new fluoronaphthyridone. Antimicrob. Agents Chemother. 50 (6), 2261-2264. doi: 10.1128/AAC.01407-05

Park, M., Wu, P., Goldstein, E., Joo Kim, W., and Cowling, B. J. (2016). Influenzaassociated excess mortality in South Korea. Am. J. Prev. Med. 50 (4), e111-e119. doi: 10.1016/j.amepre.2015.09.028

Paukner, S., Gelone, S. P., Arends, S. J. R., Flamm, R. K., and Sader, H. S. (2019). Antibacterial activity of Lefamulin against pathogens most commonly causing community-acquired bacterial pneumonia: SENTRY antimicrobial surveillance program (2015-2016). Antimicrob. Agents Chemother. 63 (4), e02161-18. doi: 10.1128/AAC.02161-18

Peleg, A. Y., Weerarathna, T., McCarthy, J. S., and Davis, T. M. (2007). Common infections in diabetes: pathogenesis, management and relationship to glycaemic control. Diabetes Metab. Res. Rev. 23 (1), 3-13. doi: 10.1002/dmrr.682

Perrone, T., and Quaglia, F. (2017). Lung US features of severe interstitial pneumonia: case report and review of the literature. J. Ultrasound 20 (3), 247249. doi: 10.1007/s40477-017-0241-x

Peto, L., Nadjm, B., Horby, P., Ngan, T. T., van Doorn, R., Van Kinh, N., et al. (2014). The bacterial aetiology of adult community-acquired pneumonia in Asia: a systematic review. Trans. R. Soc. Trop. Med. Hyg. 108 (6), 326-337. doi: $10.1093 /$ trstmh/tru058

Pfaller, M. A., Flamm, R. K., Mendes, R. E., Streit, J. M., Smart, J. I., Hamed, K. A., et al. (2019). Ceftobiprole activity against gram-positive and -negative pathogens collected from the United States in 2006 and 2016. Antimicrob. Agents Chemother. 63 (1), e01566-18. doi: 10.1128/AAC.01566-18

Pfaller, M. A., Huband, M. D., Rhomberg, P. R., and Flamm, R. K. (2017a). Surveillance of omadacycline activity against clinical isolates from a global collection (North America, Europe, Latin America, Asia-Western Pacific), 2010-2011. Antimicrob. Agents Chemother. 61 (5), e00018-17. doi: 10.1128/AAC.00018-17

Pfaller, M. A., Mendes, R. E., Castanheira, M., Flamm, R. K., Jones, R. N., and Sader, H. S. (2017b). Ceftaroline activity tested against bacterial isolates causing community-acquired respiratory tract infections and skin and skin structure infections in pediatric patients from United States Hospitals: 2012-2014. Pediatr. Infect. Dis. J. 36 (5), 486-491. doi: 10.1097/ INF.0000000000001477

Pfaller, M. A., Sader, H. S., Rhomberg, P. R., and Flamm, R. K. (2017c). In vitro activity of delafloxacin against contemporary bacterial pathogens from the United States and Europe, 2014. Antimicrob. Agents Chemother. 61 (4), e0260916. doi: 10.1128/AAC.02609-16

Pooley, N., Chadda, S., Madrigal, A. M., Kuessner, D., and Posthumus, J. (2014). A network meta-analysis comparing the efficacy and safety of Ceftobiprole and selected comparators in the treatment of hospital-acquired pneumonia. Value Health 17 (7), A588. doi: 10.1016/j.jval.2014.08.2012

Poulose, N., and Raju, R. (2014). Aging and injury: alterations in cellular energetics and organ function. Aging Dis. 5 (2), 101-108. doi: 10.14336/AD.2014.0500101

Rayfield, E. J., Ault, M. J., Keusch, G. T., Brothers, M. J., Nechemias, C., and Smith, H. (1982). Infection and diabetes: the case for glucose control. Am. J. Med. 72 (3), 439-450. doi: 10.1016/0002-9343(82)90511-3

Reid, A. B., Daffy, J. R., Stanley, P., and Buising, K. L. (2010). Use of pristinamycin for infections by gram-positive bacteria: clinical experience at an Australian hospital. Antimicrob. Agents Chemother. 54 (9), 3949-3952. doi: 10.1128/ AAC.00212-10

Rhee, C. K., Chang, J. H., Choi, E. G., Kim, H. K., Kwon, Y. S., Kyung, S. Y., et al. (2015). Zabofloxacin versus moxifloxacin in patients with COPD exacerbation: a multicenter, double-blind, double-dummy, randomized, controlled, Phase III, non-inferiority trial. Int. J. Chron. Obstruct. Pulmon. Dis. 10, 2265-2275. doi: 10.2147/COPD.S90948

Richardson, D. M., Medvedeva, E. L., Roberts, C. B., and Linkin, D. R. (2015). Comparative effectiveness of high-dose versus standard-dose influenza vaccination in community-dwelling veterans. Clin. Infect. Dis. 61 (2), 171-176. doi: $10.1093 / \mathrm{cid} / \mathrm{civ} 261$

Riquelme, S. A., Ahn, D., and Prince, A. (2018). Pseudomonas aeruginosa and Klebsiella pneumoniae adaptation to innate immune clearance mechanisms in the lung. J. Innate. Immun. 10 (5-6), 442-454. doi: 10.1159/000487515
Roblin, P. M., Kutlin, A., Sokolovskaya, N., and Hammerschlag, M. R. (1997). In-vitro activity of dirithromycin against Chlamydia pneumoniae. J. Antimicrob. Chemother. 39 (5), 647-649. doi: 10.1093/jac/39.5.647

Roychoudhury, S., Makin, K., Twinem, T., Leunk, R., and Hsu, M. C. (2016). In vitro resistance development to Nemonoxacin in Streptococcus pneumoniae: a unique profile for a novel nonfluorinated quinolone. Microb. Drug Resist. 22 (7), 578-584. doi: 10.1089/mdr.2016.0021

Rubinstein, E., Lalani, T., Corey, G. R., Kanafani, Z. A., Nannini, E. C., Rocha, M. G., et al. (2011). Telavancin versus vancomycin for hospital-acquired pneumonia due to gram-positive pathogens. Clin. Infect. Dis. 52 (1), 31-40. doi: $10.1093 / \mathrm{cid} /$ ciq031

Sabria, M., Pedro-Botet, M. L., Gomez, J., Roig, J., Vilaseca, B., Sopena, N., et al. (2005). Fluoroquinolones vs macrolides in the treatment of Legionnaires disease. Chest 128 (3), 1401-1405. doi: 10.1378/chest.128.3.1401

Scheeren, T. W. (2015). Ceftobiprole medocaril in the treatment of hospitalacquired pneumonia. Future Microbiol. 10 (12), 1913-1928. doi: 10.2217/ fmb. 15.115

Schmid, P., Rauber, D., Betsch, C., Lidolt, G., and Denker, M. L. (2017). Barriers of influenza vaccination intention and behavior - a systematic review of influenza vaccine hesitancy, 2005 - 2016. PLoS One 12 (1), e0170550. doi: 10.1371/ journal.pone.0170550

Sharma, L., Losier, A., Tolbert, T., Dela Cruz, C. S., and Marion, C. R. (2017). Atypical pneumonia: updates on Legionella, Chlamydophila, and Mycoplasma Pneumonia. Clin. Chest Med. 38 (1), 45-58. doi: 10.1016/j.ccm.2016.11.011

Shay, D. K., Chillarige, Y., Kelman, J., Forshee, R. A., Foppa, I. M., Wernecke, M., et al. (2017). Comparative effectiveness of high-dose versus standarddose influenza vaccines among US medicare beneficiaries in preventing Postinfluenza deaths during 2012-2013 and 2013-2014. J. Infect. Dis. 215 (4), 510-517. doi: 10.1093/infdis/jiw641

Siala, W., Kucharíková, S., Braem, A., Vleugels, J., Tulkens, P. M., MingeotLeclercq, M. P., et al. (2016). The antifungal caspofungin increases fluoroquinolone activity against Staphylococcus aureus biofilms by inhibiting $\mathrm{N}$-acetylglucosamine transferase. Nat. Commun. 7, 13286. doi: 10.1038/ ncomms 13286

Song, W. J., and Chang, Y. S. (2017). Respiratory allergies in the elderly: findings from the Korean longitudinal study on health and aging phase I study (20052006). Asia Pac. Allergy 7 (4), 185-192. doi: 10.5415/apallergy.2017.7.4.185

Stamnes, M. A., Rutherford, S. L., and Zuker, C. S. (1992). Cyclophilins: a new family of proteins involved in intracellular folding. Trends Cell Biol. 2 (9), 272 276. doi: 10.1016/0962-8924(92)90200-7

Stets, R., Popescu, M., Gonong, J. R., Mitha, I., Nseir, W., Madej, A., et al. (2019). Omadacycline for community-acquired bacterial pneumonia. N. Engl. J. Med. 380 (6), 517-527. doi: 10.1056/NEJMoa1800201

Stevens, D. L., Ma, Y., Salmi, D. B., McIndoo, E., Wallace, R. J., and Bryant, A. E. (2007). Impact of antibiotics on expression of virulence-associated exotoxin genes in methicillin-sensitive and methicillin-resistant Staphylococcus aureus. J. Infect. Dis. 195 (2), 202-211. doi: 10.1086/510396

Still, J. G., Schranz, J., Degenhardt, T. P., Scott, D., Fernandes, P., Gutierrez, M. J., et al. (2011). Pharmacokinetics of solithromycin (CEM-101) after single or multiple oral doses and effects of food on single-dose bioavailability in healthy adult subjects. Antimicrob. Agents Chemother. 55 (5), 1997-2003. doi: 10.1128/ AAC.01429-10

Stockman, L. J., Bellamy, R., and Garner, P. (2006). SARS: systematic review of treatment effects. PLoS Med. 3 (9), e343. doi: 10.1371/journal.pmed.0030343

Tai, W., Wang, Y., Fett, C. A., Zhao, G., Li, F., Perlman, S., et al. (2017). Recombinant receptor-binding domains of multiple middle east respiratory Syndrome Coronaviruses (MERS-CoVs) induce cross-neutralizing antibodies against divergent human and camel MERS-CoVs and antibody escape mutants. J. Virol. 91 (1), e01651-16. doi: 10.1128/JVI.01651-16

Tao, X., Mei, F., Agrawal, A., Peters, C. J., Ksiazek, T. G., Cheng, X., et al. (2014). Blocking of exchange proteins directly activated by cAMP leads to reduced replication of middle east respiratory syndrome coronavirus. J. Virol. 88 (7), 3902-3910. doi: 10.1128/JVI.03001-13

Taylor, D. N., Treanor, J. J., Sheldon, E. A., Johnson, C., Umlauf, S., Song, L., et al. (2012). Development of VAX128, a recombinant hemagglutinin (HA) influenza-flagellin fusion vaccine with improved safety and immune response. Vaccine 30 (39), 5761-5769. doi: 10.1016/j.vaccine.2012.06.086 
Troeger, C., Forouzanfar, M., Rao, P. C., Khalil, I., Brown, A., Swartz, S., et al. (2017). Estimates of the global, regional, and national morbidity, mortality, and aetiologies of lower respiratory tract infections in 195 countries: a systematic analysis for the Global Burden of Disease Study 2015. Lancet Infect. Dis. 17 (11), 1133-1161. doi: 10.1016/s1473-3099(17)30396-1

Van Buynder, P. G., Konrad, S., Van Buynder, J. L., Brodkin, E., Krajden, M., Ramler, G., et al. (2013). The comparative effectiveness of adjuvanted and unadjuvanted trivalent inactivated influenza vaccine (TIV) in the elderly. Vaccine 31 (51), 6122-6128. doi: 10.1016/j.vaccine.2013.07.059

van Rensburg, D. J., Perng, R. P., Mitha, I. H., Bester, A. J., Kasumba, J., Wu, R. G., et al. (2010). Efficacy and safety of nemonoxacin versus levofloxacin for community-acquired pneumonia. Antimicrob. Agents Chemother. 54 (10), 4098-4106. doi: 10.1128/AAC.00295-10

Varner, T. R., Bookstaver, P. B., Rudisill, C. N., and Albrecht, H. (2011). Role of rifampin-based combination therapy for severe community-acquired Legionella pneumophila pneumonia. Ann. Pharmacother. 45 (7-8), 967-976. doi: 10.1345/aph.1Q074

Vergis, E. N., Indorf, A., File, T. M., Jr., Phillips, J., Bates, J., Tan, J., et al. (2000). Azithromycin vs cefuroxime plus erythromycin for empirical treatment of community-acquired pneumonia in hospitalized patients: a prospective, randomized, multicenter trial. Arch. Intern. Med. 160 (9), 1294-1300. doi: 10.1001/archinte.160.9.1294

Veve, M. P., and Wagner, J. L. (2018). Lefamulin: Review of a Promising Novel Pleuromutilin Antibiotic. Pharmacotherapy 38 (9), 935-946. doi: 10.1002/ phar.2166

von Grotthuss, M., Wyrwicz, L. S., and Rychlewski, L. (2003). mRNA cap-1 methyltransferase in the SARS genome. Cell 113 (6), 701-702. doi: 10.1016/ S0092-8674(03)00424-0

Waites, K. B., Crabb, D. M., Duffy, L. B., Jensen, J. S., Liu, Y., and Paukner, S. (2017a). In vitro activities of Lefamulin and other antimicrobial agents against macrolide-susceptible and macrolide-resistant mycoplasma pneumoniae from the United States, Europe, and China. Antimicrob. Agents Chemother. 61 (2), e02008-16. doi: 10.1128/AAC.02008-16

Waites, K. B., Crabb, D. M., Liu, Y., and Duffy, L. B. (2016). In vitro activities of Omadacycline (PTK 0796) and other antimicrobial agents against human mycoplasmas and ureaplasmas. Antimicrob. Agents Chemother. 60 (12), e02008-16. doi: 10.1128/AAC.01734-16

Waites, K. B., Xiao, L., Liu, Y., Balish, M. F., and Atkinson, T. P. (2017b). Mycoplasma pneumoniae from the respiratory tract and beyond. Clin. Microbiol. Rev. 30 (3), 747-809. doi: 10.1128/CMR.00114-16

Wang, L., Shi, W., Joyce, M. G., Modjarrad, K., Zhang, Y., Leung, K., et al. (2015). Evaluation of candidate vaccine approaches for MERS-CoV. Nat. Commun. 6, 7712. doi: $10.1038 /$ ncomms 8712

Waterer, G. W., Somes, G. W., and Wunderink, R. G. (2001). Monotherapy may be suboptimal for severe bacteremic pneumococcal pneumonia. Arch. Intern. Med. 161 (15), 1837-1842. doi: 10.1001/archinte.161.15.1837

Webley, W. C., and Hahn, D. L. (2017). Infection-mediated asthma: etiology, mechanisms and treatment options, with focus on Chlamydia pneumoniae and macrolides. Respir. Res. 18 (1), 98. doi: 10.1186/s12931-017-0584-Z

Winterbauer, R. H., Bedon, G. A., and Ball, W. C., Jr. (1969). Recurrent pneumonia. Predisposing illness and clinical patterns in 158 patients. Ann. Intern. Med. 70 (4), 689-700. doi: 10.7326/0003-4819-70-4-689
Wong, C. M., Yang, L., Chan, K. P., Leung, G. M., Chan, K. H., Guan, Y., et al. (2006). Influenza-associated hospitalization in a subtropical city. PLoS Med. 3 (4), e121. doi: 10.1371/journal.pmed.0030121

Woodhead, M., Blasi, F., Ewig, S., Garau, J., Huchon, G., Ieven, M., et al. (2011). Guidelines for the management of adult lower respiratory tract infections-summary. Clin. Microbiol. Infect. 17 (s6), E1-E59. doi: 10.1111/j.1469-0691.2011.03602.x

Wunderink, R. G., Rello, J., Cammarata, S. K., Croos-Dabrera, R. V., and Kollef, M. H. (2003). Linezolid vs vancomycin: analysis of two doubleblind studies of patients with methicillin-resistant Staphylococcus aureus nosocomial pneumonia. Chest 124 (5), 1789-1797. doi: 10.1016/ S0012-3692(15)33412-7

Yakovlev, S. V., Stratchounski, L. S., Woods, G. L., Adeyi, B., McCarroll, K. A., Ginanni, J. A., et al. (2006). Ertapenem versus cefepime for initial empirical treatment of pneumonia acquired in skilled-care facilities or in hospitals outside the intensive care unit. Eur. J. Clin. Microbiol. Infect. Dis. 25 (10), 633 641. doi: 10.1007/s10096-006-0193-0

Yu, H., Feng, L., Viboud, C. G., Shay, D. K., Jiang, Y., Zhou, H., et al. (2013). Regional variation in mortality impact of the $2009 \mathrm{~A}(\mathrm{H} 1 \mathrm{~N} 1)$ influenza pandemic in China. Influenza Other Respir. Viruses 7 (6), 1350-1360. doi: 10.1111/irv.12121

Yuan, J., Mo, B., Ma, Z., Lv, Y., Cheng, S. L., Yang, Y., et al. (2019). Safety and efficacy of oral nemonoxacin versus levofloxacin in treatment of communityacquired pneumonia: a phase 3, multicenter, randomized, double-blind, double-dummy, active-controlled, non-inferiority trial. J. Microbiol. Immunol. Infect. 52 (1), 35-44. doi: 10.1016/j.jmii.2017.07.011

Zhang, Y. F., Dai, X. J., Yang, Y., Chen, X. Y., Wang, T., Tang, Y. B., et al. (2016). Effects of probenecid and cimetidine on the pharmacokinetics of nemonoxacin in healthy Chinese volunteers. Drug Des. Devel. Ther. 10, 357-370. doi: 10.2147/ DDDT.S95934

Zhong, N. S., Sun, T., Zhuo, C., D’Souza, G., Lee, S. H., Lan, N. H., et al. (2015). Ceftaroline fosamil versus ceftriaxone for the treatment of Asian patients with community-acquired pneumonia: a randomised, controlled, double-blind, phase 3, non-inferiority with nested superiority trial. Lancet Infect. Dis. 15 (2), 161-171. doi: 10.1016/S1473-3099(14)71018-7

Zmira, S., Orit, O., and Haim, S. (2005). Susceptibility of methicillin-resistant Staphylococcus aureus to vancomycin, teicoplanin, linezolid, pristinamycin and other antibiotics. Israel Med. Assoc. J. 7 (3), 148-150. doi:10.1007/ s00108-004-1340-2

Zumla, A., Chan, J. F., Azhar, E. I., Hui, D. S., and Yuen, K. Y. (2016). Coronaviruses - drug discovery and therapeutic options. Nat. Rev. Drug Discov. 15 (5), 327 347. doi: $10.1038 / \mathrm{nrd} .2015 .37$

Conflict of Interest: The authors declare that the research was conducted in the absence of any commercial or financial relationships that could be construed as a potential conflict of interest.

Copyright (c) 2019 Liu, Zhang, Zhao, Liu, Hu and Dong. This is an open-access article distributed under the terms of the Creative Commons Attribution License (CC BY). The use, distribution or reproduction in other forums is permitted, provided the original author(s) and the copyright owner(s) are credited and that the original publication in this journal is cited, in accordance with accepted academic practice. No use, distribution or reproduction is permitted which does not comply with these terms. 